dini araștırmalar dergisi

Turkish Journal of Religious Studies

cilt / volume: $21 \bullet$ sayı / issue: $1 \bullet$ yaz / summer 2021

\title{
Prof. Dr. M. Zeki Duman ve İlmi Çalışmaları
}

\section{Prof. M. Zeki Duman and His Works}

\section{Mehmet Kaya}

Doç. Dr., Selçuk Üniversitesi İslami İlimler Fakültesi, Tefsir Anabilim Dalı

Assoc. Prof., Selçuk University, Faculty of Islamic Sciences, Department of Hermeneutics

Konya / Turkey

kayamehmet1453@hotmail.com | https://orcid.org/0000-0003-0066-5232

\section{Article Type / Makale Tipi}

Research Note / Araştırma Notu

DOI: $10.33420 /$ marife. 913309
Article Information / Makale Bilgisi

Received / Gelis Tarihi: 18.02.2021

Accepted / Kabul Tarihi: 21.06.2021

Published / Yayın Tarihi: 30.06.2021

Cite as / Atıf: Kaya, Mehmet. "Prof. Dr. M. Zeki Duman ve İlmi Çalıșmaları". Marife 21/1 (2021), 647-679. https://doi.org/10.33420/marife.913309

Plagiarism / Intihal: This article has been reviewed by at least two referees and scanned via a plagiarism software. / Bu makale, en az iki hakem tarafından incelendi ve intihal içermediği teyit edildi.

\section{(c) (1) $(9)$}

Copyright / Telif Hakk: "This article is an open access article distributed under the terms and conditions of the Creative Commons Attribution-NonCommercial-NoDerivatives 4.0 (CC BY-NC-ND 4.0) International License." / "Bu makale Creative Commons Alıntı-GayriTicari-Türetilemez 4.0 (CC BY-NCND 4.0) Uluslararası Lisansı altında lisanslanmıștır."

e-ISSN: $2630-5550$

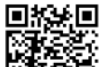




\section{Prof. Dr. M. Zeki Duman ve İlmi Çalışmaları}

Özet

Bu çalışmada Erciyes Üniversitesi İlahiyat Fakültesi Öğretim Üyelerinden merhum Prof. Dr. M. Zeki Duman'ın hayatı ve eserleri ele alınacaktır. Duman, yașadığı dönemde ülkemizdeki tefsir akademisyenlerinin duayenlerinden olmasının yanı sira bir tefsir eseri kaleme alan ender ilim adamlarından biridir. Duman, mezun olduğu ve o dönemdeki ismi Kayseri Yüksek İslâm Enstitüsü olan Erciyes Üniversitesi İlahiyat Fakültesi'nde otuz yıldan fazla görev yapmış bu süre zarfında bugün bir kısmı çeșitli İlahiyat Fakültelerinde akademisyen olan çok sayıda öğrenci yetiştirmiştir. 2009-2012 yılları arasında dekanlık görevini de icra eden Duman, fakültenin fiziki ve akademik altyapısının güçlenmesine de önemli katkı sağlamıștır. Yazdığı eserlerde tefsir alanına ilişkin problemli konuları ve sosyal sorunları aydınlatmaya odaklanan Duman, kendisini Fakülte sınırlarına hapseden bir akademisyen olmamıștır. O, Beyânu'l-Hak tefsiri başta olmak üzere çeşitli eserleriyle toplumun sorunlarına ışık tutmaya çalıșmış bir ilim adamıdır. Kendi adındaki internet sitesiyle isteyenlerin bu bilgilere kolay ve ücretsiz ulaşmalarını da sağlamıştır. Uzun yıllar boyunca haftanın dört günü çeşitli meslek gruplarıyla yaptığı derslerle ve yurt içi ve yurt dışında verdiği konferanslarla sahip olduğu birikimi halkla da paylaşmıştır. Naif bir kişiliğe sahip olmakla birlikte profesyonel olarak sporla da ilgilenen Duman yardımsever kişiliğiyle ve bu noktadaki girişimleriyle de tanınmaktadır. Duman 10 Temmuz 2013 tarihinde geçirdiği trafik kazası sonucunda hayatını kaybetmiștir. Duman'ın eserlerinin çoğu hayattayken yayımlanmakla birlikte bir kısmı vefatının ardından evlatlarının girişimiyle yayımlanmıştır. Duman'ın tamamlayamadığı eserleri de mevcuttur. Biz bu çalıșmada tefsir alanına uzun yıllar boyunca hizmet eden ve çok sayıda eser kaleme alan Duman'ın hayatı ve eserleri hakkında bilgi vererek onun ve eserlerinin tanınmasına katkı sağlamayı hedeflemekteyiz.

Anahtar Kelimeler: Tefsir, M. Zeki Duman, İlmi Çalışmalar, Erciyes Üniversitesi İlahiyat Fakültesi, Beyânu'l-Hak.

\section{Prof. M. Zeki Duman and His Works}

\section{Summary}

In this study, the life of Professor M. Zeki Duman who is a lecturer in the Faculty of Theology of Erciyes University, and his works will be discussed. In addition to being one of the doyens of tafsir scholars in our country during his lifetime, Duman is one of the rare scholars who wrote a work of tafsir. Duman who graduated from Erciyes University Faculty of Theology, whose name was Kayseri High Islamic Institute at that time, has taught many students, some of whom are academicians in various Theology Faculties today. Duman who also served as the dean between 2009-2012, made a significant contribution to the strengthening of the physical and academic infrastructure of the faculty. Duman, who focuses on enlightening the problematic issues and social problems related to commentary in his works was not an academician who confined himself to the boundaries of the Faculty. He is a scholar who tried to shed light on the problems of society with his various works, especially the interpretation of Beyânu'l-Haq. He tried to help people reach this information easily and freely through his website. He shared his knowledge with people through weekly meetings that were made four times a week with different occupation groups and by conferences in Turkey and other countries. He was a tenderminded person and did sports professionally. Duman was also known for his helpful personality and initiatives on this issue. Duman passed away as a result of a traffic accident on 10 July 2013. Although most of Duman's works were published in his lifetime, some of them were published on the initiative of his children after his death. There are also some works that Duman could not complete. In this study, we aim to contribute to the recognition of Duman and his works by providing information about his life and works, for he has served in the field of tafsir for many years and wrote many works.

Keywords: Commentary, M. Zeki Duman, Scientific Works, Erciyes University Faculty of Theology, Beyanul-Haq.

\section{Giriș}

Merhum Prof. Dr. M. Zeki Duman Tefsir Anabilim Dalı'nda bir kısmı alanın problemli konularına ışık tutan çok sayıda eseriyle tanınan ve tefsir eserine sahip ender akademisyenlerden biridir. Duman, Erciyes Üniversitesi İlahiyat Fakülte- 
si'nde uzun yıllar görev yapmış ve lisans, yüksek lisans ve doktora düzeylerinde çok sayıda öğrenci yetiştirmiştir.

Duman sadece akademik çalışmalarıyla öne çıkan bir ilim adamı olmamış; İlahiyat Fakültelerinde görev yapan akademisyenlerden beklenen halkla bütünleşmeyi başaran ender şahsiyetlerden biri olmuştur. Duman, kaleme aldığı çok sayıda kitap, makale ve bildiri ile tefsir sahasına önemli katkılar sağlamıștır. Beyânu'l-Hakk, Kur'an'ı Kerim'de Âdâb-ı Muâșeret, Beș Sûrenin Tefsiri, Nüzu-

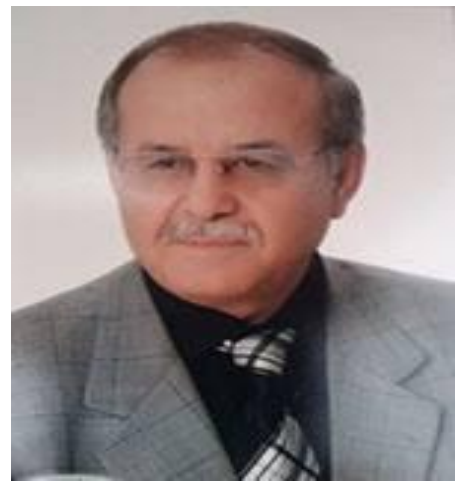
lünden Günümüze Kur'an ve Müslümanlar gibi eserleriyle toplumsal konulara eğildiği görülen Duman, insanları Kur'an'la buluşturduğu gibi onlara Kur'an ve sünnete uygun bir yaşam biçiminin yolunu da göstermiştir. Katıldığ çok sayıdaki konferansla ve çeşitli mesleklerdeki insanlara yönelik sürekli olarak yaptığı tefsir dersleriyle "Halka hizmet Hakk'a hizmettir" düsturuyla hareket etmiştir. Şahsi hayatında Kur'an ve Rasulullahı rehber edinen Duman, yetiştirdiği çok sayıdaki öğrencinin hocası olmakla kalmamıș, onlara yönelik maddi manevi destekleriyle adeta onların babası olmuştur. Beyânu'l-Hak ve Adâb-ı Muaşeret adlı eserleri gerek akademik camia gerekse toplum nezdinde büyük ilgi gören Duman'ın bazı eserleri akademik çalışmalara konu olmuştur. ${ }^{1}$ Bununla birlikte tefsir ilmine hem eserleri hem de bireysel çabaları ile hizmet etmiş olan Duman ve eserlerine yönelik kapsamlı bir çalışma yapılmadığı görülmüştür. Bu çalışmada ilmi ve ahlaki vasıflarıyla öne çıkan merhum Duman ve onun tefsir ilmine yönelik eserleri hakkında bilgi verilerek onun, tefsir ilmine yönelik katkıları hakkında genel bir fikir oluşturulması hedeflenmektedir.

${ }^{1}$ Duman'ın eserleri hakkında yapılmış akademik çalışmalar şunlardır: Naif Yaşar, "Beyânu'l-Hak Adlı Meâl-Tefsir Üzerine Bir Eleştiri”, Recep Tayyip Erdoğan Üniversitesi İlahiyat Fakültesi Dergisi 2 (2012), 193-232; Necmettin Çalıșkan, "Nüzul Sırasına Göre Tefsir Yaklaşımının Kur'an Yorumuna Etkisi (Beyanu'l-Hak Örneği)”, Mustafa Kemal Üniversitesi Sosyal Bilimler Enstitüsü Dergisi 14/40 (2017), 398-422; Muhammed Fatih Arslanhan, “M. Zeki Duman’ın Kur'an-ı Kerim ve Tıbba Göre Tüp Bebek Görüşü", Uluslararası Sosyal ve Beșeri Bilimler Araştırma Dergisi 6/41 (2019), 2359-2367; Melahat Akalp, Metodu ve Konuları Itibariyle Beyânu'l-Hak Tefsiri (Konya: Necmeddin Erbakan Üniversitesi, Yüksek Lisans Tezi, 2013); Mustafa Çıklaçifci, M. Zeki Duman'ın Beyânu'l-Hak İsimli Tefsirindeki Hadislerin Tahrici ve Değerlendirilmesi (Kayseri: Erciyes Üniversitesi, Yüksek Lisans Tezi, 2017); Musa Güler, Nüzûl Sırasını Esas Alan Tefsirlerin Mukayesesi (Et-Tefsîru'l-Hadîs, Fehmu'lKur'âni'l-Hakîm ve Beyânu'l-Hak Örneği) (Van: Yüzüncü Yıl Üniversitesi, Doktora Tezi, 2018); Meryem Okudan, Beyânu'l-Hakk ve Kur'ân Yolu Tefsirlerinin Ulûmu'l-Kur'ân Açısından Değerlendirilmesi (Samsun: Ondokuz Mayıs Üniversitesi, 2019); Hızır Hacımustafaoğlu, Ulûmu'l-Kur'an Bağlamında Hamdi Yazır ve Zeki Duman Tefsirlerinin Mukayesesi (Samsun: Ondokuz Mayıs Üniversitesi, Yüksek Lisans Tezi, 2020). 


\section{Hayatı}

M. Zeki Duman, 1952 Yılında Sivas'ın Şarkışla ilçesi, Gümüştepe Köyü'nde doğdu. İlkokulu köyünde bitirdi. Orta öğretiminin ilk bölümünü Sivas, ikinci bölümünü Kayseri İmam-Hatip Lisesi'nde 1969 yılında tamamladı. Aynı yıl, hariçten fark dersleri sınavlarını vererek Kırşehir Atatürk Lisesi'nden lise diploması aldı. 30 Haziran 1973 tarihinde Kayseri Yüksek İslâm Enstitüsü'nden mezun oldu. 19731977 yılları arasında dört yıl Kırklareli İmam-Hatip Lisesi’nde meslek dersleri öğretmenliği ve müdür yardımcılığı görevlerinde bulundu. 13 Nisan-31 Ekim 1975 tarihleri arasında Isparta'da kısa dönem askerlik görevini tamamladı. 26 Haziran 1977 tarihinde Kayseri Yüksek İslâm Enstitüsü'ne tefsir asistanı olarak atandı. 18 Nisan 1984 tarihinde Uludağ Üniversitesi Sosyal Bilimler Enstitüsü'nde Tefsir Bilim Dalında doktor, 25 Kasım 1987 tarihinde doçent, 11 Haziran 1993 tarihinde profesör unvanlarını aldı. 02 Ekim 2009-31 Aralık 2012 tarihleri arasında Erciyes Üniversitesi İlahiyat Fakültesi dekanlığı da yapan Duman, İlahiyat Fakülteleri Dekanlar Kurulu'nun kurulmasına da öncülük etmiștir.

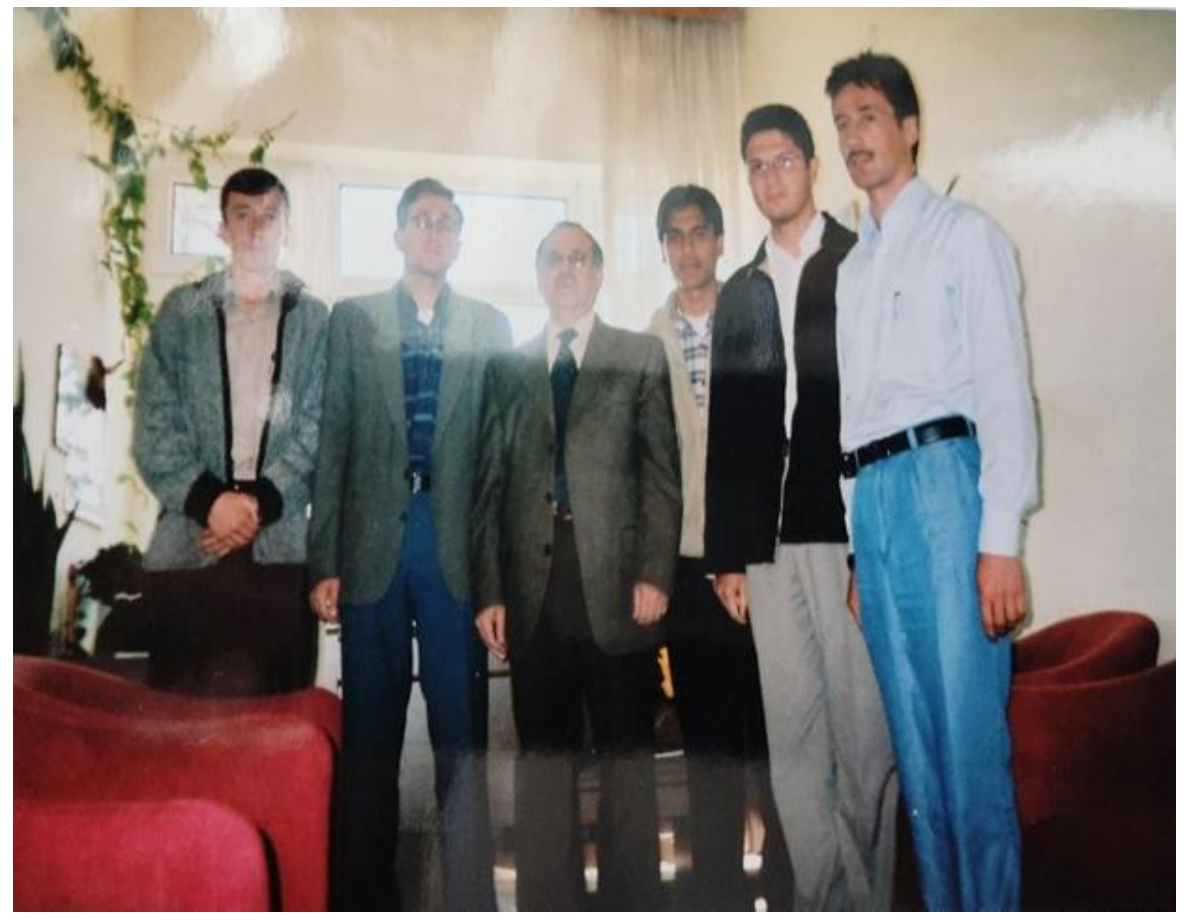


Duman idari görevler de üstlenmiş; Tefsir Anabilim Dalı Başkanlığı, Fakülte Kurulu Üyeliği, Fakülte Yönetim Kurulu Üyeliği, Sosyal Bilimler Enstitüsü Yönetim Kurulu Üyeliği, Temel İslam Bilimleri Bölümü Başkanlığı ve Erciyes Üniversitesi Yurtdışı Takip Komitesi Üyeliği görevlerinde bulunmuştur. Erciyes Üniversitesi İlahiyat Fakültesi Temel İslâm Bilimleri Bölümü Tefsir Anabilim Dalında Başkanı olarak çalışmalarını sürdürmekte iken 10 Temmuz 2013 tarihinde elim bir trafik kazasında Hakk'ın rahmetine kavuşmuştur. Üç çocuk babası olan Duman, Arapça ve Fransızca bilmekteydi. ${ }^{2}$

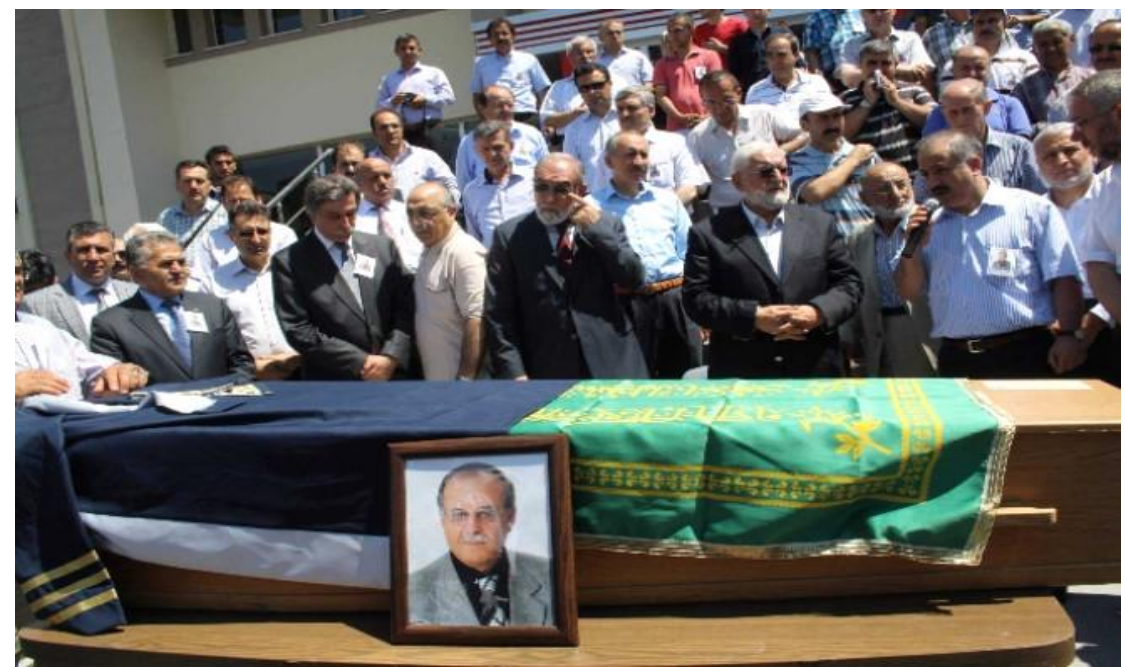

Naif kişiliğe sahip olan Duman Allah’ın kelamını anlatırken yer yer kendini tutamayarak gözyaşı dökerdi. Güreşle de profesyonel olarak ilgilenen Duman, üniversite güreş takımının da antrenörlügünü yapmıştır. Yirmi yıl boyunca yönettiği Fakülte Yardımlașma Sandığı'nı kurarak faizsiz borçlanma ve yardımlașma geleneğini ihya etmiştir.

Duman ilmin zekatını hakkıyla veren nadir kişilerdendi. Bir tefsir profesörüne yakışacak sorumluluk ve çalışma azminin tebarüz ettiği ender ilim adamlarındandı. İlim adamlığı vasfının içini hakkıyla dolduran, kendini sürekli geliştiren profesör bir öğrenciydi adeta. Katı geleneksel zihniyetin donuklaştırdığı, her türlü yeni düşünce ve söyleme kapılarını kapatan İslam terakkisine karşı makul bir duruş sergileyen ve bu özelliğiyle kendi yașıtları arasında öne çıkan birisiydi. Görevini hakkıyla yapmayan meslektaşlarına yeri geldikçe sitem eder ve onları harekete geçirmeye gayret ederdi. ${ }^{3}$

2 Duman'ın hayatı hakkında bk. M. Zeki Duman, “Ailede Çocuk Eğitimi ve Lokman Hakim'in Oğluna Nasihatlerinin Düșündürdükleri”, Diyanet İlmi Dergi 27/3 (1991), 103; İslâm'da Namaz ve Teheccüd (Ankara: Fecr Yayınları, 2013), 4; İslam’ın Üzerindeki Beş Gölge -Nesh, Recm, Köle ve Cariye, Ehl-i Beyt ve Hz. İsa'nın Dönüşü, (Ankara: Fecr Yayınları, 2018), 4-6; http://zekiduman.com (Erişim: 28.05.2020); Melahat Akalp, Metodu ve Konuları Itibariyle Beyânu'l- Hak Tefsiri (Konya: Necmeddin Erbakan Üniversitesi, Yüksek Lisans Tezi, 2013), 2.

${ }^{3}$ Duman, İslam’ın Üzerindeki Beş Gölge, (Hüseyin Nazlı Aydın’ın, esere yazdığı takdimden) s. 7. 


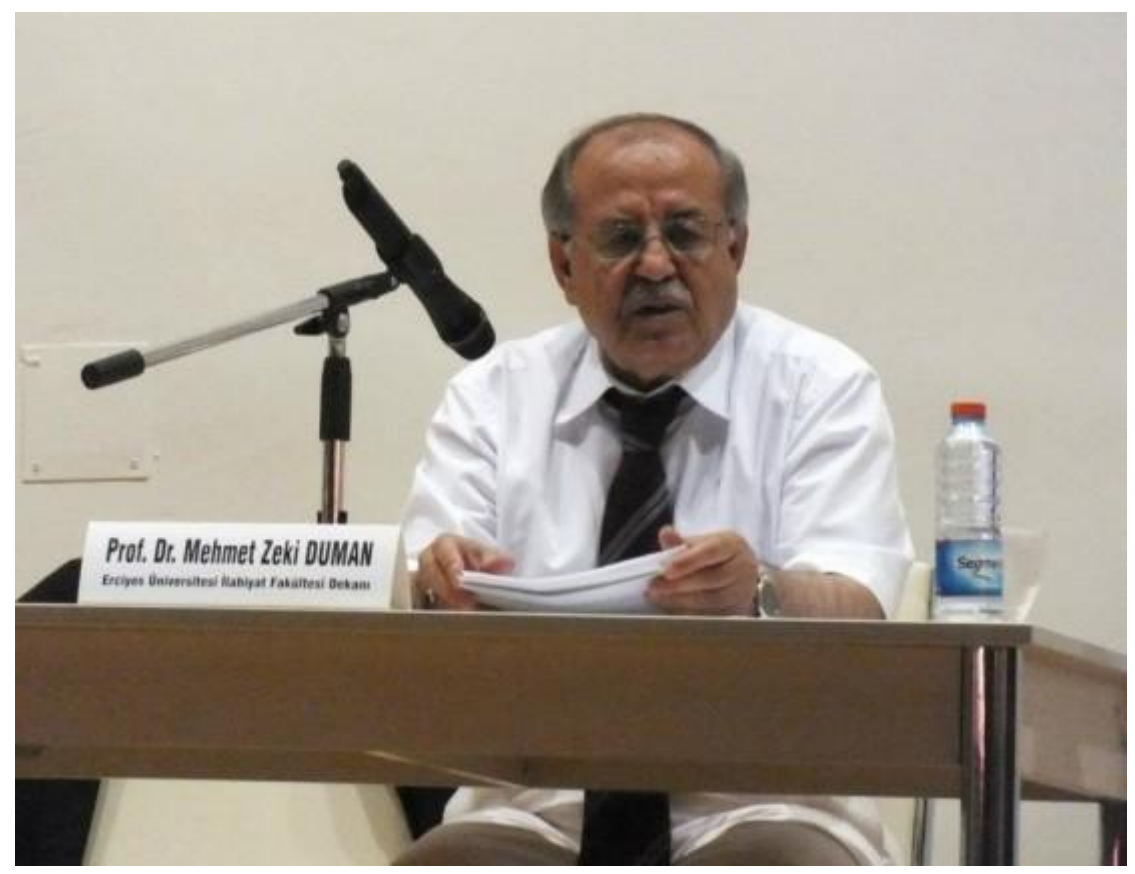

\section{2. İlmi Çalışmaları}

M. Zeki Duman'ın telif kitap, makale, bildiri, ansiklopedi maddesi ve çeviriden oluşan birçok eserinin yanı sıra danışmanlığını yaptığı lisans, yüksek lisans ve doktora tezleriyle de akademik hayata katkı sağlamıştır. ${ }^{4}$ Duman kendine ait internet sitesinden eserlerini, konferans metinlerini ve güncel bazı konular hakkındaki görüşlerini paylaşarak daha geniş kitlelere hizmet etme gayreti içerisinde olmuştur. ${ }^{5}$

\subsection{Telif Kitapları}

Duman'ın hayattayken tamamladığı bazı eserleri vefatından sonra evlatları tarafından yayımlanmış, bununla birlikte bazı eserleri tamamlanamamıştır.

\footnotetext{
${ }^{4}$ Akademik dünyaya adımın ilk basamağını yüksek lisans aşaması oluşturduğu için bu çalışmada Merhum Duman'ın danıșmanlığını yaptığı lisans tezlerine yer verilmeyecektir.

${ }^{5}$ Bu konuda bk. Duman, http://www.zekiduman.com.
} 


\subsubsection{Beyânu'l-Hak (Kur'ân-ı Kerîm'in Nüzul Strasına Göre Tefsiri)}

Fecr Yayınevi tarafindan ilk defa 2006 yılında yayımlanan bu eserin 2008, 2016 ve 2020 yllarında olmak üzere dört baskısı yapılmış, eser 2016 yılında Kayseri Gündem Gazetesi tarafindan da abonelerine dağıtılmıştır. Sûrelerin nüzûl sırasına göre tefsir edildiği bu eserde ilk olarak Fatiha sûresi, son olarak ise Nasr sûresi tefsir edilmiştir. Sûre sıralamalarının Hz. Osman'ın Mushafına göre yapıldığı ve yer yer bazı sûrelerin sıralamasında değişikliğe gidildiği belirtilen ${ }^{6}$ eserin ilk iki cildinde Mekkî, son cildinde ise denî sûreler tefsir edilmiştir. Eserin son cildinde ise

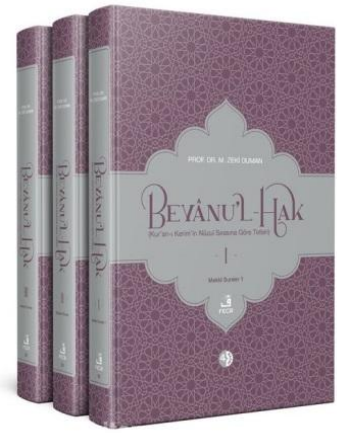
sûrelerin Mushaf tertibine göre, nüzûlüne göre ve alfabetik olarak sıralandığı üç tabloya yer verilmiştir. Eserin her cildinin sonunda anahtar kelimelerin anlamlarını içeren kısa bir sözlüğe yer verilmiştir.

Fatiha sûresinin mealine önsöz olarak yer verildiği görülen eserde on yedi sayfalık bir giriş yer almaktadır. Müellif bu girişte tefsirini bitirmesi sebebiyle Allah’a olan şükrünü yerine getirdikten sonra yükümlülük ve sorumluluk taşıyan bir kul olması sebebiyle bu tefsiri kaleme aldığını belirtir. ${ }^{7}$ Kur'an'ın insanların güncel $^{\prime}$ ihtiyaçları için indirildiğini belirten Duman, onun lafız ve anlam itibariyle mu'ciz bir kitap olduğunu belirtir. Kur'an'ın harfî tercümesinin mümkün olmadığı kanaatini taşıyan Duman, meallerin yöntem sorunu sebebiyle okuyucuyu tatmin edemediği gibi fahiş hatalar içerdiğini belirtir. ${ }^{8}$

Bu ifadelerin ardından "Neden yeni bir tefsir?" başlığına yer veren Duman, bu başlıkta tefsir yazma sebebi ve tefsir yöntemi hakkında bilgi verir. Türkiye'de yayımlanmış meal ve tefsirlerin maksut manayı Türkçeye aktarma ve açıklamada yetersiz olduklarını, gereksiz bilgilerle yorumu uzattıklarını, âyetlere bütüncül bir bakış açısıyla ve nüzûl sıralamasına göre yaklaşamadıklarını belirtir. Meallerde âyetlere çoğunlukla bağlamlarından koparılarak parçacı biçimde yaklaşıldığını ve yorumların birbirinden kopya edildiği için geçmiște yapılan hataların tekrarlandığını belirten Duman, iyi niyetin ve ciddi bir gayretin ürünü olduğunu belirttiği tefsirlerin geniş olması, ilgisiz açıklamalar içermesi, önemli konulara bütüncül ve yeterli açıklama getirememesi, âyetlere evrensel ve güncel niteliklerin yansıtılmaması sebebiyle okuyucuyu tatmin edemediği gibi usandırdığını belirtir. ${ }^{9}$

Beyânu'l-Hak tefsirinin otuz iki yılı aşkın mesleki hayat ve yirmi sekiz yıllık akademik geçmiş sonucu oluşan tefsir bilinci ile altı yıllık yoğun ve aralıksız bir çalışmanın ürünü olduğunu belirten Duman, son iki yllı tekrar tekrar okunarak kelimeler ve tematik paragraflar arası incelikleri araștırdığını ve bu incelikleri en

6 Duman, Beyânu'l-Hak (Kur'ân-ı Kerîm'in Nüzul Sırasına Göre Tefsiri) (Ankara: Fecr Yayınları, 2006), $1 / 15$

7 Duman, Beyânu'l-Hak, 1/19.

${ }^{8}$ Duman, Beyânu'l-Hak, 1/10-11.

${ }^{9}$ Duman, Beyânu'l-Hak, 1/11. 
uygun şekilde Türkçeye yansıtmaya çalıștığını belirtir. Bu yönüyle İslam dünyasında ilk olduğunu belirttiği bu tefsirin bugüne kadar derli toplu olarak kaleme alınmadığını belirttiği tefsir yöntemini/uygulamalı metot bilgisini içerdiğini ifade eder. ${ }^{10}$

"Tefsir, Te'vil ve Aralarındaki Farklar" başlığında bu iki kavrama ve aralarındaki farklara değinen Duman te'vilin tefsirden sonra gelen bir zihinsel faaliyet olduğunu, her iki yöntemde zarf mazruf ilişkisi içerisinde bütüncül bir anlama yönteminin önemine dikkat çeker. ${ }^{11}$

Duman özetle yirmi üç maddede tefsirinin özelliklerini şu şeklide sıralar:

1. Gazali'nin belirttiği tefsirin, Kur'an'ın en fazla üç misli yapılması gerektiği yönündeki "tefsirde iktisat" yolu seçilmiştir.

2. Kur'an'ın indiriliş ortamına uygun olması açısından tefsirde nüzûl sıralamasının temel alınmış, bunun için sûrelerin sıralamasında Hz. Osman'a nispet edilen nüshadaki esas alınmakla birlikte müellifin gerekçesini belirtmediği lüzum üzerine bu sıralamada az da olsa değişiklik yapılmıştır.

3. Her sûrenin tefsirinden önce o sûrenin meali, sûrenin tarihi ve kültürel arka planı ile -varsa- nüzûl sebebi hakkında bilgi verilmiştir.

4. Her sûre aynı anda indirilen ve müellifin pasaj olarak nitelediği âyet ya da âyet grupları ve tarihi arka plan (Mekkîlik/Medenîlik) göz önünde bulundurularak tefsir edilmiştir.

5. Âyetler bilimsel, evrensel ve daima çağdaş ve güncel açıdan okunmuş ve okuyucu ile "Kelâmullah" arasında sürekli, bütüncül ve sağlıklı bir iletişimin kurulmasına dikkat edilmiştir.

6. Açıklamalar âyetin muradına uygun olarak yapılmış, gereksiz uzatmalara ve tartışmalara girilmemiş, sıhhati belirsiz rivayetlere başvurulmamış, dilbilimsel açıklamalar gerektiği kadar ve sadece mana açısından yapılmıştır.

7. Her âyet müstakil olarak yorumlanmamıș, yorumlar tematik paragraflar halinde ve pasaj eksenli yapılmıştır.

8. Âyetler, iç bütünlük, siyak-sibak bütünlüğü, pasaj bütünlüğü sünnet dahil tarihi arka plan bütünlügü ve Kur'an bütünlüğü esasına göre tefsir edilmiştir. Yer yer parantez ve eğik çizgi (/) ilaveleriyle mana daha net anlaşılır hale getirilmeye çalışılmıştır.

9. Âyetin anlamı verilirken Türkçedeki ses ve söz uyumuna dikkat edildiğinden literal anlam terk edilmiş ve âyetin temel anlamıyla yetinilerek ziyade anlamlar okuyucuya bırakılmıştır.

10. Genel anlayıștan farklı olarak Kur'an'da neshin olmadığı ve müteșabih âyetlerin te'vil edilebileceği düşüncesinde olan Duman, tefsirinde bu konudalarki yerleşik düşüncenin aksine bir yorum yöntemi takip edeceğini belirtir.

11. Tefsirde Kur'an, hadis, sahabe ve tahkik ehl-i müfessirlerle ilim adamla-

10 Duman, Beyânu'l-Hak, 1/11.

11 Duman, Beyânu'l-Hak, 1/12-13. 
rının görüşlerine dayanılarak ilmihal, usul ve ulûmu'l-Kur'ân bilgilerine ilişkin bilgiler verilmiş, konuya ilişkin kelime ve kavramlar hakkında yer yer dipnotta açıklamalar yapılmıştır.

12. Âyetlerin meali verilirken Türkçeye en uygun karşllıklar verilmeye, sanatsal ifadeler, incelikler ve vurgular yansıtılmaya çalışılmıştır.

13. Metin içi bağlam ve tarihi/kültürel bağlama aykırı yorumlardan kaçınılmiştır.

14. Mümkün olduğu ölçüde âyetler konuya ilişkin başka âyetlerle açıklanmaya çalışılmış, sıhhati şüpheli rivayetlerden kaçınılmıştır.

15. Âyetin lafzına, metin içi ve metin dışı bağlamına ve Kur'an bütünlüğüne ters düşen hadisler tercih edilmemiştir.

16. Hiçbir tefsirin son sözü söyleyemeyeceği gerçeğinden hareketle yorumlarda çağın ilim ve kültür düzeyi gözetilmiştir.

17. Modernizmin etkisiyle âyetlere maksadını aşacak anlamlar yüklenmemiş, hiçbir âyete Batı uygarlığının üretmiş olduğu anlayışa ve savunucularının görüşlerine uygun olma kastıyla yaklaşılmamıştır.

18. Kısır tartışmalara yol açmamak adına daha önce kaleme alınmış olan meal ve tefsirlerdeki hatalara yönelik eleștiri yapılmamış, âyetin lafzına en uygun anlam verilerek aklî ve naklî sağlam delillerle desteklenmiştir.

19. Arapça bilen okuyucuların ayetlere verilen manaları tekrar düşünmelerini kolaylaştırmak amacıyla her cildin sonunda bazı anahtar kelimelerin anlamlarl, okuyuşuyla birlikte verilmiştir.

20. Sade, akıcı ve her düzeyden insanın anlayacağı bir dil kullanılmaya özen gösterilerek Kur'an özellikle genç neslin anlayışına yaklaştırılmaya çalışılmış, Türkçede yer etmiş dini kavramlar tercüme edilmemiştir.

21. Cümle kuruluşlarında Arapça metne bağlı kalınmakla birlikte Türkçedeki ifade biçimine de önem verilmiştir.

22. Âyetin anlamına katkı sağlamak için yer yer Türkçedeki deyim, atasözü ve şiirlerden yararlanılmıştır. Kur'an'da kullanılan bir deyimin Türkçede karşılığı varsa onunla ifade edilmiştir.

23. Eserde, başlangıçtan bugüne dek yazılmış birçok tefsirden ve birkaç mealden yararlanılmakla birlikte bu eserlerdeki bilgiler mezkûr prensipler çerçevesinde değerlendirilmiştir. Eserde, Arap dili, modern bilim ve realiteye aykırı bilgilere yer verilmemeye özen gösterilmiş, bu çerçevede önceki tefsirlerde sadece dil merkezli ele alınan bazı ifadeler modern bilimin verileriyle temellendirilerek kullanılmıştır. Söz gelimi önceki tefsirlerde sadece sözlük anlamı üzerinden anlamlandırılan "alak" kelimesi için "rahme tutunan", "nutfe" kelimesi için "sperm" ve "nutfe-i emșâc" terkibi için "zigot" kullanımı tercih edilmiștir.

Duman tefsirine ilişkin bu özelliklere değindikten sonra hakikati yansıtma prensibinden ayrılmadığını, yükümlülük ve sorumluluk şuuruyla hareket ettiğini belirtir. Farklı ilim adamlarıyla müzakerede bulunup en uygun anlamı yazdığını belirten Duman, tefsire mezhebi aidiyeti yansıtmadığını, tefsirini samimi bir niyet- 
le kaleme aldığını ve yapıcı eleştiriye de açık olduğunu ifade eder. ${ }^{12}$

Eserde her sûrenin girişinde sûrenin nerede ve ne zaman indiği, ismi, âyet sayısı, Hz. Osman ve Ebûbekr'in Mushaflarındaki sıralamaları ve içeriği hakkında bilgi verilmiștir. ${ }^{13}$ Ağırlıklı olarak âyetin âyetle tefsiri metodunun uygulandığı eserde $^{14}$ yer yer hadisle tefsir metoduna da başvurulmuştur. ${ }^{15}$ Eserde yer yer kelimelerin kökü ve anlamları hakkında da bilgi verilmiştir. ${ }^{16}$ Bazı sûre ve âyetlerin Türk kültüründeki yerine değinildiği görülen eserde ${ }^{17}$ bazı âyetlerin mealleri verilirken Türkçedeki kullanımlara değinilmiştir. ${ }^{18}$ Yer yer Türk diline ait şiir ve tekerlemelerden yararlanılan eserde ${ }^{19}$ bazı âyetlerin yorumları resimlerle desteklenmiştir. $^{20}$

Müteşabihat kabul edilen hurûf-ı mukattaanın tefsir edilmediği eserde bazı yorumlar eleştirilmektedir. ${ }^{21}$ Eserde kevnî âyetlerin yorumunda modern bilimin verilerinden ve buna yönelik kaynaklardan yararlanılmaktadır. ${ }^{22}$ Eserde bazı konular yaşamın içinden örnekler üzerinden somutlaştırılmaktadır. ${ }^{23}$ Yer yer âyetteki belagat hakkında bilgi verilen eserde ${ }^{24}$ az da olsa kelimelerin i'râb vechine değinilmektedir. ${ }^{25}$

Rivayet metodunun kullanıldığı eserde Zemahșerî'nin (ö. 538/1144) el-

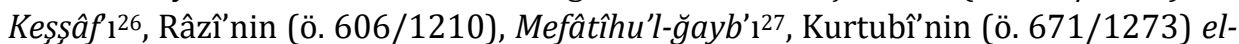
Câmi' li-ahkâmi'l-Kur'ân'l, ${ }^{28}$ Nesefî̀nin (ö. 710/1310) Medâriku't-tenzîlli29, İbn Kesîr'in (ö. 774/1373) Tefsîru'l-Kur'âni'l-azîm'i30 ve Elmalılı Hamdi Yazır'ın (ö. 1942) Hak Dini Kur'an Dili ${ }^{31}$ adlı eseri en çok bașvurulan tefsir kaynaklarıdır. Eserde son dönemde kaleme alınan farklı alanlardaki çeşitli kaynaklardan da yararlanılmıștır. ${ }^{32}$

\footnotetext{
12 Duman, Beyânu'l-Hak, 1/14-25.

13 bk. Duman, Beyânu'l-Hak, 1/29, 41, 125; 2/9, 175, 443; 3/9, 193, 285-286, 405 vd.

14 bk. Duman, Beyânu'l-Hak, 1/71, 73, 149, 170, 210, 388, 417, 493; 2/19, 75, 265, 352; 3/34, 112, 251, $402,542 \mathrm{vd}$

15 bk. Duman, Beyânu'l-Hak, 1/66, 227, 303; 2/133, 165, 373; 3/88, 120, 226, 363 vd.

16 bk. Duman, Beyânu'l-Hak,1/31-33, 126-127; 2/325, 481, 517; 3/ 79, 312, 500-503 vd.

17 Duman, Beyânu'l-Hak, 1/29.

18 Duman, Beyânu'l-Hak, 1/355, 394, 489; 2/164.

19 bk. Duman, Beyânu'l-Hak, 1/103, 337; 2/ 36, 245, 314, 539; 3/76, 423, 524 vd.

${ }^{20}$ Duman, Beyânu'l-Hak, 3/384, 388.

${ }^{21}$ Duman, Beyânu'l-Hak, 1/37, 127.

22 Duman, Beyânu'l-Hak, 1/398, 275; 2/14, 108, 275, 517; 3/360.

${ }^{23}$ Duman, Beyânu'l-Hak, 1/267; 2/61, 279; 3/126, 324, 542.

${ }^{24}$ Duman, Beyânu'l-Hak, 2/30, 123.

${ }^{25}$ Duman, Beyânu'l-Hak, 2/346.

${ }^{26}$ bk. Duman, Beyânu'l-Hak, 1/264; 2/103, 3/114, 244, 363, 538 vd.

27 Duman, Beyânu'l-Hak, 1/34; 2/307; 3/56.

28 bk. Duman, Beyânu'l-Hak, 1/364; 2/106, 235; 3/105, 236, 363 vd.

${ }^{29}$ bk. Duman, Beyânu'l-Hak, 1/66, 428, 442; 2/116, 235, 270, 365; 3/24, 28, 125, 300 vd.

${ }^{30}$ Duman, Beyânu'l-Hak, 1/66, 227, 364; 2/107, 149, 235, 331; 3/36, 114, 225, 312.

31 bk. Duman, Beyânu'l-Hak, 1/297, 319, 337, 2/116, 198, 331, 334; 3/90, 224, 319, 506 vd.

32 Duman, Beyânu'l-Hak, 1/146, 258; 2/21, 160, 3/3115, 305, 504.
} 


\subsubsection{Kur'anı Kerim'de Adâbı Muașeret}

Prof. Dr. Ahmet Coşkun'un yönetiminde 1984 yllında Uludağ Üniversitesi Sosyal Bilimler Enstitüsü'nde Kur'an-ı Kerim'de Muâşeret Esasları adıyla doktora tezi olarak hazırlanan bu eser ${ }^{33}$ ilk defa Kur'an-ı Kerim'de Sosyal Münasebetler Âdâb-ı Muaşeret adıyla yayımlanmıștır. ${ }^{34}$ Çeşitli yayınevleri tarafından bazı isim değişiklikleriyle farklı tarihlerde basılan ${ }^{35}$ bu eser 2011 yılında Yenişafak Gazetesi tarafından da dağıtılmıştır.

Eser dört bölümden oluşmaktadır. Eserin önsözünde ahlak ve onun pratik hayattaki yansıması olduğu belirtilen âdâb-ı muaşeretin öneminden bahsedilmiş, bu eserin konuya iliş̧in ilk ciddi çalışma olduğu, önce-

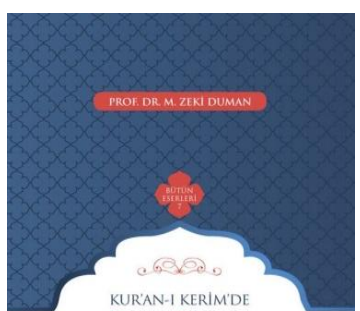

ÂDÂB-I MUÂŞERET ki çalışmaların dar çerçevede ve Batı anlayışına göre kaleme alındığı belirtilmiştir. Ardından âdâb-ı muaşeretin toplum için öneminden bahsedilmiş ve eser kaleme alınırken takip edilen yöntem ve kaynaklar hakkında bilgi verilmiştir. ${ }^{36}$

Birinci bölümde edeb, muâş̧eret kavramları ile sosyal hayatın gerekliliği, edebin önemi, âdâb-ı muâş̧eretin kaynağı konularına değinilmiştir. ${ }^{37}$

“Özel İlişkilerden Muâşeret Esasları” bașlıklı ikinci bölümde Hz. Peygamberle ilişkilerde, Hz. Peygamberin hanımlarıyla, karı-koca ilişsilerinde, Ebeveyn-evlat ilişkilerinde, kadın-erkek ilişkilerinde, öğretmen-öğrenci ilişkilerinde, komşuluk ilişkilerinde, gayr-i Müslimlerle ilişkilerde, yetim ve kimsesizlerle ilişkilerde, fakirlerle ilişkilerde, köle ve cariyelerle ilişkilerde ve âmir-memur ilişkilerindeki adaba çeşitli alt başlıklarda değinilmiştir. ${ }^{38}$

"Yakınlaştırıcı Nitelikte Genel İlişkiler" başlıklı üçüncü bölümde selamlaşma, misafirlik ve ziyaret adabına değinilmiştir. ${ }^{39}$

"Şahsa Özgü Hal ve Davranışlar" başlıklı dördüncü bölümde ise temizlik, giyim-kuşam adabı ve başkalarına saygılı olmak konularına değinilmiştir. ${ }^{40}$

Eserin "Netice" başlı̆̆ında ise her bölüme ilişkin kitabın özetine yer verilmiștir. ${ }^{41}$

33 bk. İsmail E. Erünsel vd. İlahiyat Fakülteleri Tezler Kataloğu I (1953-2000) (İstanbul: İsam Yayınları, 2008), 938.

${ }^{34}$ Duman, Kur'an-ı Kerim'de Sosyal Münasebetler Âdâb-ı Muașeret (Kayseri: Dilek Matbaası, 1982).

${ }^{35}$ Eser Kur'an-ı Kerim'de Adab-ı Muaşeret Görgü Kuralları (İstanbul: Tuğra Neşriyat 1986); Adab-ı Muaşeret Görgü Kuralları (İstanbul: İpek Yayın Dağıtım, 2003, 2011); Kuranı Kerimde Adabı Muaşeret Görgü Kuralları (Ankara: Fecr Yayınları, 2017). Şeklinde farklı yayınevleri tarafından farklı tarihlerde basılmıștır.

${ }^{36}$ bk. Duman, Adab-ı Muaşeret Görgü Kuralları (İstanbul: İpek Yayın Dağıtım, 2003), 13-18.

37 Duman, Adab-ı Muaşeret, 19-38.

${ }^{38}$ Duman, Adab-ı Muașeret, 40-277.

${ }^{39}$ Duman, Adab-ı Muaşeret, 279-330.

${ }^{40}$ Duman, Adab-ı Muaşeret, 331-375.

${ }^{41}$ bk. Duman, Adab-ı Muaşeret, 377-385. Bu eser gençlere yönelik "Ufka Yolculuk Yarışması" için Muhlise Arzu Peçenek tarafından yazılan iletişim bölümü eklenerek "İletişim, Nezaket ve Âdâb" adıyla Server Yayınları tarafından çeşitli tarihlerde İstanbul'da basılmıştır. 


\subsubsection{Kur'an-ı Kerim ve Tıbba Göre İnsanın Yaratılışı ve Tüp Bebek Hadisesi}

Küçük hacimli bu eser alışılagelen üsluptan farklı olarak eserde her iki konu I. ve II. Kitap başlıklarıyla incelenmektedir. Eserin önsözünde Kur'an-bilim ilişkisine değinildikten sonra müellif bu eseri kaleme alma sebebine değinir ve Erciyes Üniversitesi Konferans Salonunda tüp bebek konusunda verilen konferans sonrasinda İslam'ın bu konuda nasıl bir tavır aldığı yönündeki soruların ardından bu eseri kaleme aldığını belirtir. ${ }^{42}$ Duman, tıbbın verileri ile âyet ve hadislere getirilen yorumların değişkenlik arz etmesi sebebiyle konuyu âyet ve hadislerdeki lafızlar ekseninde ele aldığını belirtir. Bununla birlikte müfessirlerin âyetler hakkındaki yorumlarını tenkit süzgecinden geçirerek ele aldığını ve tıbbın verilerine dayandığını, bununla birlikte "âyetin anlamı budur"

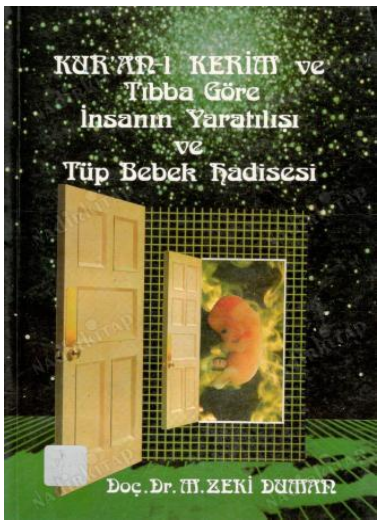
şeklinde kesin bir yargıda bulunmadığını belirtir. ${ }^{43}$

Eserin girişinde cenin ile ilgili âyetlere ve yorumlarına değinilmiş, Kur'an'ın insan yaratılışını sudan, topraktan ve nutfeden olmak üzere üç aşamada ele aldığı belirtilmiştir. ${ }^{44}$

İlk bölümde meni ve nutfenin tanımı ile her ikisinin oluşum ve özelliklerine âyet, hadis ve tıp ilimlerinin verileri çerçevesinde değinildikten ${ }^{45}$ sonra ikinci bölümde döllenmiş yumurtanın ana rahmine yerleștirilmesi, ${ }^{46}$ üçüncü bölümde ceninin ana rahminde geçirdiği safhalar ${ }^{47}$ dördüncü bölümde ise ceninin yaratılışını tamamlaması âyet, hadis ve tıbbın verileri çerçevesinde ele alınmıştır. ${ }^{48}$

Sonuçta Kur'an'ın embriyoloji kitabı olmamasına rağmen bu konuda ciltler dolusu kitap yazmaya müsait kapsamlı âyetler ihtiva ettiği, bu bilgilerin tıbbın verileriyle çelişmediği, bilim adamlarının Kur'an'ın bu konudaki verilerini göz önünde bulundurması gerektiği ve her çağda Kur'an'dan alınabilecek malumat olduğu ifade edilmiştir. ${ }^{49}$ Ardından tüp bebeğin uygulanışı hakkında görselle desteklenmiş tarihi ve teknik bilgilere yer verilmekte ve bu uygulamanın sadece çocuk sahibi olamayan evli çiftlerde tedavi amaçlı kullanılması gerektiği vurgulanmıştır. ${ }^{50}$

\footnotetext{
42 Duman, Kur'an-ı Kerim ve Tıbba Göre İnsanın Yaratılışı ve Tüp Bebek Hadisesi (İzmir: Nil Yayınları, 1991), V-V.

${ }^{43}$ Duman, Kur'an-ı Kerim ve Tıbba Göre Insanın Yaratılışı, V-VI.

${ }_{44}$ Duman, Kur'an-ı Kerim ve Tıbba Göre İnsanın Yaratılışı, 1-7.

${ }^{45}$ Duman, Kur'an-ı Kerim ve Tıbba Göre İnsanın Yaratılışı, 8-20.

${ }^{46}$ Duman, Kur'an-ı Kerim ve Tıbba Göre Insanın Yaratılışı, 21-25.

${ }^{47}$ Duman, Kur'an-ı Kerim ve Tıbba Göre İnsanın Yaratılışı, 27-42.

48 Duman, Kur'an-ı Kerim ve Tıbba Göre Insanın Yaratılıșı, 43-46.

${ }^{49}$ Duman, Kur'an-ı Kerim ve Tıbba Göre Insanın Yaratılışı, 47-49.

${ }^{50}$ Duman, Kur'an-ı Kerim ve Tıbba Göre Insanın Yaratılışı, 51-61.
} 


\subsubsection{Uygulamalı Tefsir Usulü ve Tefsir Tarihi (Başlangıcından Tedvin Döne- mine Kadar)}

Eser 1992 yılında Erciyes Üniversitesi Yayınları'ndan çıkmıştır. Bir giriş ve altı bölümden oluşan eserin önsözünde Kur'an'ı anlamak için onu dinleme, anlama ve âyetlerini düşünmenin gerekliliğine değinildikten sonra onun getirdiği ilkeler doğrultusunda yaşamak gerektiği ifade edilmiştir. Kur'an'ı anlamanın kendine özgü yöntemleri olduğu ve bu yöntemlere de "Tefsir Usulü" denildiğini belirten Duman, bu eserin 1985 yllından beri tefsir usulü ile ilgili peyderpey yaptığı çalışmaların tamamından oluştuğunu ifade etmektedir. Eserde önceki çalışmalardan farklı olarak vahiy başta olmak üzere tefsirle ilgili ana kavramların derinlemesine incelendiği ve her konunun üçer âyetten örnekler verilerek açıklandığı belirtilmiştir. Âyetlerin gündemden düşmeyenler arasından seçilmesinin bu eseri önceki çalışmalardan farklı kılan bir diğer özellik olduğu belirtilmiştir. ${ }^{51}$

Eser bir giriş ve altı bölümden oluşmaktadır. Eserin girişinde Kur'an-ı Kerim'in tefsirine duyulan ihtiyaç, bazı âyetlerin tefsir edilme mecburiyeti ve $\mathrm{Hz}$. Peygamberin tebliğ ve tefsir görevi hakkında bilgi verilmiştir. ${ }^{52}$

Tefsirle ilgili özel terimlerin ele alındığı birinci bölümde Kur'an, vahiy, tefsir, te'vil, meâl ve tercüme terimleri hakkında bilgi verilmiş, ayrıca Kur'an'ın isimleri ve vahyin çeşitleri, mahiyeti, gerçekleşmesi, Kur'an'ın Hz. Muhammed'e indiriliş şekilleri ve vahiy karşısında Hz. Muhammed'in konumu hakkında bilgi verilmiştir. ${ }^{53}$

"Asr-ı Saadette Tefsirin Kaynakları ve Tefsir Şekilleri" başlıklı ikinci bölümde ise Kur'an'ın Kur'an'la tefsiri hakkında bilgi verilmiş; Kur'an'daki âyetler anlaşılması bakımından muhkem ve müteşabih olarak ele alınmıştır. Bu bölümde Kur'an'ın üslubu hakkında da bilgi verilmiştir. "Kur'an'ın Hadislerle Tefsiri” başlığında ise Rasulullah'ın tefsir metotları, tefsir şekilleri ve tefsir ettiği âyetlerin miktarı hakkında bilgi verilmiștir. ${ }^{54}$

"Sahabenin Tefsiri" başlıklı üçüncü bölümde ise sahabenin tefsiri ve değeri, bazı müfessir sahabiler hakkında bilgi verilmiștir. ${ }^{55}$

"Tabiun ve Tefsiri” başlıklı dördüncü bölümde ise tabiunu tefsire sevk eden amiller ve ilk tefsir medreseleri ile bu medreselerde yetişen önde gelen müfessirler ele alınmış, tabiunun tefsir kaynakları ve tabiun tefsirinin genel özellikleri ve değe-

\footnotetext{
${ }^{51}$ Duman, Uygulamalı Tefsir Usulü ve Tefsir Tarihi (Başlangıcından Tedvin Dönemine Kadar) (Kayseri: Erciyes Üniversitesi Yayınları, 1992), VII-VIII.

52 Duman, Uygulamalı Tefsir Usulü, IX-XII.

${ }^{53}$ Duman, Uygulamalı Tefsir Usulü, 1-63.

${ }^{5}$ Duman, Uygulamalı Tefsir Usulü, 65-115.

55 Duman, Uygulamalı Tefsir Usulü, 117-130.
} 
ri hakkında bilgi verilmiştir. ${ }^{56}$

"Tefsirin Tedvini ve Tefsir Çeşitleri” başlıklı beşinci bölümde tefsirin tedvini, çeşitleri ele alınmış; bu kapsamda rivayet tefsiri ve kaynakları, rivayet tefsirinin zaaf noktaları, israiliyyâtın hükmü, meşhur rivayet tefsirleri ile dirâyet tefsiri, bu konudaki ihtilaflar ele alınmış ve meşhur rivayet tefsirlerinden örneklere yer verilmiştir. ${ }^{57}$

"Kur'an Tefsirinde İhtilaf Sebepleri" başlıklı altıncı ve son bölümde ise sahabenin, ehl-i bidatin ve Ehl-i sünnetin ihtilafları ve bu ihtilafların sebepleri incelenmiştir. ${ }^{58}$

\subsubsection{Nüzulünden Günümüze Kur'an ve Müslümanlar (Nasıl Okudular, Nasıl Okumaliyız?)}

İlk baskısı 1996 yılında Fecr Yayınevi tarafindan yapılan eserin 1997, 2006, 2010, 2013 ve 2016 yıllarında olmak üzere altı baskısı yapılmıştır. Eser bir giriș ve üç bölümden oluşmaktadır. Eserin önsözünde Kur'an kelimesinin "okumak" anlamına dikkat çekilmiş ve Kur'an okumanın biri âyetlerini okuyup, kavrayıp yaşamak, ikincisi de yazılı olmayan kevnî âyetleri inceleyip, düşünmek ve ibret almak olduğu ifade edilmiştir. Bunun da Kur'an'ı anlayarak okumakla mümkün olduğu; bununla birlikte günümüz insanlarının Kur'an'ı anlamadan okudukları ve bu eserle de Müslümanları uyarmak ve Kur'an'ı gerçek manada okumaya teşvik

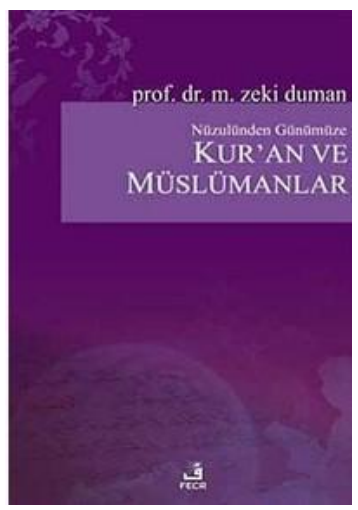
etmenin amaçlandığı belirtilmiştir. ${ }^{59}$ Eserin birinci bölümünde Kur'an'ın özellikleri, tenzil ve tertil ile indirilişi, Kur'an'ın indiriliș amacı, Kur'an'ın üslubu, Kur'an'ın evrensel niteliği, Kur'an'ın kâinata bakışı, Kur'an'da insana verilen değer, Kur'an'ın hayat anlayıșı hakkında bilgi verilmiștir. ${ }^{60}$

Eserin “Asr-ı Saadette Kur’an ve Müslümanlar” başlıklı ikinci bölümünde ise asr-ı saadetin tanımı, ilk eğitim ve öğretim yılları, sistemli eğitim ve öğretim yılları, Kur'an öğreniminde uygulanan metot, sahabe döneminde Kur'an'ın ezberlenmesi, Kur'an öğrenim ve öğretimini teşvik, sahabe Kur'an ilişsisi ve etki düzeyi, ölülere Kur'an okuyup telkinde bulunmak, Hulefa-i Raşidin döneminde Kur'an ve Müslümanların Kur'an'la ilişkisi ve Kur'an'ı anlamadan ezberlemenin yanlışlığına değinilmiştir. 61

Hulefa-i Râşidîn dönemi sonrası Müslümanların Kur'an ile olan ilişkilerinin

\footnotetext{
${ }^{56}$ Duman, Uygulamalı Tefsir Usulü, 131-154.

57 Duman, Uygulamalı Tefsir Usulü, 157-178.

58 Duman, Uygulamalı Tefsir Usulü, 179-186.

59 Duman, Nüzulünden Günümüze Kur'an ve Müslümanlar (Nasıl Okudular, Nasıl Okumalıyız?) (Ankara: Fecr Yayınları, 1997), 11-15.

${ }^{60}$ Duman, Nüzulünden Günümüze Kur'an ve Müslümanlar, 35-132.

${ }^{61}$ Duman, Nüzulünden Günümüze Kur'an ve Müslümanlar, 135-176.
} 
ele alındığı üçüncü bölümde ise inananların hayatlarında ortaya çıkan yeniliklerin onların Kur'an anlayışını değiștirdiği, Hz. Osman'ın şehadetiyle ortaya çıkan büyük fitnenin inanalar arasında ayrışmalara sebep olduğu, bu durumun onların Kur'an'dan uzaklaşmalarını hızlandırdığı, bu tarihten itibaren Kur'an'ın sevap için okunmaya başlandığı ifade edilmiştir. Yirminci asır Müslümanlarının birbirinden farklı İslam anlayışına sahip olduğu ve bugün yeryüzünde yaşanan İslam'ın Kur'an ve sünnetle genel çerçevesi çizilen gerçek İslam olmadığı belirtilen eserde aslından uzaklaşılarak İslam'ın bidat ve hurafelerle doldurulduğu, Türk aydınlarının bu konuda iki tavır sergilediği; laik kesimin Kur’an ve sünneti insafsızca eleştirdiği, Müslüman kesimin ise Kur'an ve sünnetin getirdiği temel ilkeleri benimseyerek onun yaklaşım tarzı ve çözüm önerilerini kabullenip önemsediği ifade edilmiş ve her iki anlayıştaki kesimin Kur'an hakkındaki hatalı tavır ve eksiklikleri hakkında bilgi verilmiştir. Ardından Cumhuriyet döneminden itibaren Türk halkının Kur'an ile olan ilişkisine değinilmiş; temelsiz fetvalar ve asılsız hadisler sebebiyle inananların Kur'an'ı anlayarak okuma eğilimlerinin yok edildiği, Kur'an kıraatinin bir meta haline getirildiği, sadece hatim indirmek, sevabını bağışlamak ya da gösteriş için okunan Kur'an'dan sevap beklenilemeyeceği ve bu uygulamaların Kur'an'ın indiriliş maksatlarına uygun olmadığı belirtilmiştir.

Anadolu'daki yanlış Kur'an algısına değinilen eserde “Kur'an'ı Okumanın Ön Şartları" başlığında Kur'an'a istiâze ile başlanması, besmele ile müsait bir hal ve ortamda içten ve sessiz biçimde okunması, bu esnada kulak ve aklın birlikte kullanılması, önyargıdan uzak okunması gerektiğine değinilmiştir. "Kuran'ı Anlayarak Okumak İçin Ne Yapılmalı?” başlığında ise Kur'an'a tekrar dönülmesi, bunun için ise Arapça öğrenilmesi gerekliliği vurgulanmıştır. Bu noktada bireysel ve toplumsal olarak yapılması gereken on öneriye yer verilen ${ }^{62}$ eserin sonuç kısmında ise Kur'an'ı anlamak için yapılması gerekenlere değinilmiştir. ${ }^{63}$

\subsubsection{Vahiy Gerçeği}

İlk baskısı 1997 yılında Fecr Yayınevi tarafından yapılan eserin ikinci baskıSı aynı yayınevi tarafından 2017 yılında yapılmıştır. Bir giriş ve üç bölümden oluşan eserin önsözünde İslam vahyinin karanlıkta kalan insanlığı aydınlatarak onlara yol gösterdiği, Kur'an'dan istifade edebilmenin ön şartının onu iyi anlamak olduğuna değinildikten sonra eserin metodu ve içeriği hakkında bilgi verilmiştir. ${ }^{64}$

Eserin girișinde ise Allah'ın insanlarla iletişiminin vahiy ile olduğuna değinildikten sonra vahyin sözlük ve terim anlamları sözlük ve âyetler çerçevesinde ele alınmıştır. ${ }^{65}$

\footnotetext{
62 Duman, Nüzulünden Günümüze Kur'an ve Müslümanlar, 179-292.

63 Duman, Nüzulünden Günümüze Kur'an ve Müslümanlar, 293-295.

${ }^{64}$ Duman, Vahiy Gerçeği (Ankara: Fecr Yayınları, 1997), 11-15.

${ }^{65}$ Duman, Vahiy Gerçeği, 17-40.
} 
"Vahyin Mahiyeti ve İnzali" başlıklı birinci bölümde ise vahyin mahiyeti, peygamberlik ruhu ve vahye katkısı, Hz. Muhammed'e vahyin indirilişi, vahiy esnasında Hz. Muhammed'in durumu, vahyin Arapça olması, kaynağı ve dili konuları ele alınmış; vahyin Allah'ın ontolojik olarak beşere tenezzülü olduğu, Hz. Peygamberin insani sıfatlarında ve ruhi yetkinliğinde yücelip kemale ermesinin vahiy olayının gerçekleşmesinde etkili olmuş olabileceği belirtilmiş, Kur'an'ın Hz. Peygamberin ürünü olmadığı, vahiy aracılığıyla Allah tarafından aktarıldığı ve orijinal şekliyle muhafaza edildiği belirtilmiştir. Vahyin dili konusuna da değini-

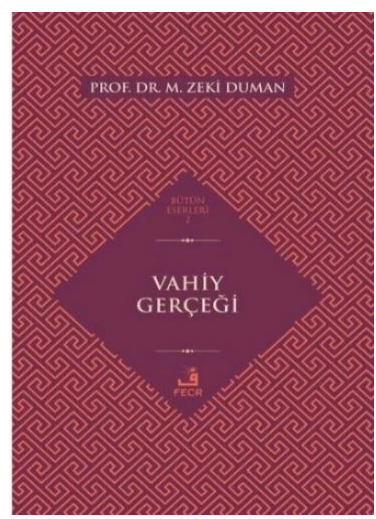
len eserde sünnetullah gereği her peygamberin, kavminin diliyle gönderilmesi ve Hz. Peygamberin Arap olması sebebiyle Kur'an'ın Arapça gönderildiği ifade edilmiștir. ${ }^{66}$

"Vahy-i gayr-i metlüvv" başlıklı ikinci bölümde ise Kur'an'dan başka vahyin olup olmadığı tartışılmış, bu kapsamda Kur’an'da Hz. Peygambere ilim ve hikmet verildiği belirtilen âyetler incelenmiş ve bu iki kavramın vahyin kapsamının dıșında olduğu belirtilmiştir. Hz. Peygambere vahyin dışında ilham edilmesinin mümkün olduğunu belirten Duman, ilim ve hikmetin Hz. Peygamberin küçük yaștan itibaren kullandığı akli ve ruhi yetkinliği sonucu oluştuğu kanaatindedir. Âyetin muradına ilişkin bilgilerin vahyin kapsamına ilişkin olarak kendisine beyan edilmiş olabileceğini belirtir. Hz. Peygamberin Kur'an tefsiri bağlamındaki açıklamalarının ilham değil vahiy olduğunu belirten Duman Hz. Peygamberin görevinin tebliğle sınırlı olmadığını ve onun ümmetine örnek bir yaşayış biçimi sergilemekle de görevli olduğunu ve bu yönüyle insanlığın peygamberlere muhtaç olduğunu belirtir. $\mathrm{Bu}$ bağlamda Hz. Peygamberin sünnetinin vahiy olmamakla birlikte onun kapsamına girdiğini belirtir. Bu bağlamda vahyi metlüvv ve vahyi gayri metlüvv ayırımına değinen Duman, bu ayırımın Rasulullahın dindeki önemini artırmayı amaçlayanlar tarafından yapıldığını; onun buna ihtiyacı olmadığını, bunu yapanların keyfi denilebilecek bir ayırıma gittiklerini ve delil olarak sundukları Necm sûresi 3. ve 4 . âyetleri yanlış yorumladıklarını belirtir. Hz. Peygamberin Kur'an dıșında vahiy almakla birlikte bu vahyin gelecekle ilgili hususları içerdiği kanaatinde olan Duman'a göre Hz. Peygamberin Kur'an'a yönelik tefsiri vahyin kapsamında değerlendirilmekle birlikte gayr-i metlüvv vahiy değildir. ${ }^{67}$

"Vahy Karşısında Hz. Muhammed” bașlıklı üçüncü bölümde Hz. Peygamberin ilk vahye muhatap oluşu, bu süreçte yaşadığı ürperti ve tebliğ ile birlikte Mekke müşriklerinin verdiği tepkileri ele alan Duman ardından Hz. Peygamberin her istediği zaman ve konuda vahiy alamadığını iki anekdot ile anlatır. Hz. Peygamberin vahye müdahalesinin mümkün olmadığını onun uyarıldığı dokuz örnek çerçeve- 
sinde anlatılır. Konuya ilişkin nakledilen Garânik olayının Hac sûresi 52. âyet çerçevesinde ele alan Duman âyetin bu olaya delalet edip etmediğinin kesinlik arz etmediğine ilişkin mütevatir ve sahih bir rivayet olmamakla birlikte bir sonraki âyette bu ilkanın Allah tarafından silinip vahyin sağlamlaştırıldığının ve Kur'an'a beșer sözü karışmadığının kesin olarak ifade edilesi sebebiyle vahye müdahalenin söz konusu olmadığını belirtir. Eserde Hz. Peygamberin vahyi tebliğde öncelik hakkı bulunmadığı ve onun unuttuğu ya da tebliğ etmediği âyet olmadığı âyetler çerçevesinde ele alınmıștır. Hz. Peygamberin masumiyeti meselesinin ele alındığı bölümün son başlığında insanların Hz. Peygamber hakkındaki yanlış düşüncelerine değinildikten sonra peygamberlerin risalet görevini yerine getirecek fiziki ve ruhi yetkinliğe sahip temiz bir karaktere sahip oldukları, ins ve cin şeytanlarından gelebilecek her türlü saldırıya karşı korundukları âyet ve rivayetler ışığında ortaya konulmuștur. 68

Sonuçta ise vahyin Allah'ın beșer ile iletişim yöntemi olduğu, peygamberlerin bu tecrübeye uygun insanlar olduğu, vahye müdahalenin olmadığı, vahyin anlaşılması için onun açıklaması olan sünnetin iyi bilinmesi gerektiği, vahyin Kur'an ile sınırlı olmadığı, Kur'an tefsiri sadedindeki bu beyanın vahyi gayr-i metlüvv olarak adlandırılamayacağı, Kur'an'a beșer sözü karıșmadığı ifade edilmiștir. ${ }^{69}$

\subsubsection{Beș Surenin Tefsiri (Fatiha, Ahzab, Nûr, Hucurat, Mümtahine)}

İlk baskısı Fecr Yayınevi tarafından 1999 yılında yapılan eserin 2010, 2013, 2019 yıllarında olmak üzere dört baskısı yapılmıștır. Eserin iç kapağında yer alan "Sosyal Muhtevalı" ifadesinden toplumsal mesajları içermesi sebebiyle bu beş sûrenin seçildiği anlaşılmaktadır. Duman, eserin önsözünde Kur'an hakkında bilgi verdikten sonra meallerin maksadı tam olarak ifade edememeleri, tefsirlerde ise konunun gereğinden fazla uzatılması sebebiyle yakın konuları içeren özgün bir tefsir yapma gereğinin hasıl olduğunu, bu sebeple sûrelerin nüzûl sırasına göre halkın ihtiyacı olan güncel bilgileri içeren bir eser kaleme aldığını belirtir. Duman, bu beş sûreyi dört eğitim yılı boyunca ders notu olarak öğrencilere anlattığını, Kur'an

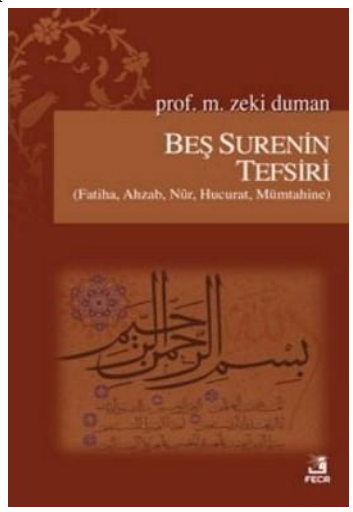
bütünlüğü çerçevesinde bu sûrelerin muhtevası zihinde olgunlaşınca yayınlamaya karar verdiğini belirtilmektedir. Müellif bu eserin ardından Allah -Kul İlişkisi Muhtevalı Beş Surenin Tefsiri II" adlı eseri kaleme almayı düşündügünü belirtmekle ${ }^{70}$ birlikte bu amacında muvaffak olamamıștır.

Sûrelerin Mushaf sıralamasına göre ele alındığı eserde ilk olarak sûrelerin isimleri, iniş sebepleri, Mushaflardaki sıralamaları, âyetlerin iniş sıralaması ve

\footnotetext{
${ }^{68}$ Duman, Vahiy Gerçeği, 151-206.

${ }^{69}$ Duman, Vahiy Gerçeği, 207-212.

70 Duman, Beş Surenin Tefsiri (Fatiha, Ahzab, Nûr, Hucurat, Mümtahine) (Ankara: Fecr Yayınları, 1999), 11-14.
} 
sûrelerin içeriği hakkında bilgi verilmektedir. ${ }^{71}$ Ardından her sûre ilk âyetten itibaren tefsir edilmekte bu süreçte yer yer sûreye ilişkin iniş sebepleri değerlendirilmektedir. ${ }^{72}$ Çeşitli müfessirlerin görüşlerinden yararlanılan eserde ${ }^{73}$ yer yer bu görüşler hakkında değerlendirmede bulunulmaktadır. ${ }^{74}$ Eserde yer yer farklı ilim dallarının verilerinden de yararlanılmaktadır. ${ }^{75}$ Eserde bazı anahtar kelimelerin anlamı açıklanmakta ${ }^{76}$ bazı kavramlar ise müstakil başlıkta ele alınmaktadır. ${ }^{77}$ Eserde yakın akraba evliliği, ${ }^{78} \mathrm{~Hz}$. Peygamberin evlilikleri, ${ }^{79} \mathrm{recm}^{80}$ gibi tartışmalı konulara da değinilmekte, yanlış olduğu belirtilen bazı düşüncelere ilişkin de düzeltmeler yapılmaktadır. ${ }^{81}$ Yer yer özgün olduğu belirtilen yaklaşımlara yer verilen eserde $^{82}$ bazı âyet gruplarının ardından değerlendirme ve sonuca yer verilmekte$\operatorname{dir} .83$

\subsubsection{Kur'an-ı Kerim'de Örtünmenin Sinırları}

Bir giriş ve üç bölümden oluşan eserin önsözünde Kur'an'ın özelliklerinden ve ona bağlılık ile tefsirinin öneminden bahseden Duman, ${ }^{84}$ Kur'an yorumunda tarihselci bakış açısı ${ }^{85}$ ile mealci yaklaşımın hatalı olduğunu belirtir. ${ }^{86}$ Kur'an yorumunda bağlam, Arap dili ve usul bilgisine vukufiyetin önemine vurgu yapan Duman bu vasıflara sahip olmayan bazı kişilerin "İlahiyatçı yazar" adı altında örtünme konusunda da çelişkili yorumlar yaparak halkı yanlış yönlendirdiklerini ve onları tedirgin ettiklerini belirtir. ${ }^{87}$ Çevreden gelen taleplerle medyadaki tartışmalar sebebiyle makale olarak yayımlanan bu çalışmayı ${ }^{88}$ müstakil bir eser olarak yayımladığını belirtir. ${ }^{89}$

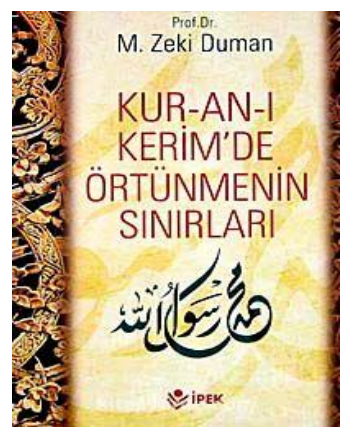

Giriște insan için örtünmenin fitrî, insani ve sosyal bir ihtiyaç olduğuna değinen Duman örtünmenin ayrıca sosyalleşmenin ilk adımı olduğunu belirtir. Her toplumda örtünmenin olduğunu belirten Duman İslam'da giyim kuşamda tek renk,

\footnotetext{
71 bk. Duman, Beş Surenin Tefsiri, 33-35, 55-57, 287.

72 bk. Duman, Beş Surenin Tefsiri, 60, 323-324.

73 bk. Duman, Beş Surenin Tefsiri, 63, 149, 161-167, 330-331 vd.

${ }^{74}$ bk. Duman, Beş Surenin Tefsiri, 167-183.

75 bk. Duman, Beș Surenin Tefsiri, 114-115, 121-122.

76 bk. Duman, Beș Surenin Tefsiri, 69, 91, 147-148, 243, 289 vd.

77 Duman, Beş Surenin Tefsiri, 235-240, 313-321.

78 bk. Duman, Beş Surenin Tefsiri, 120-122.

${ }^{79}$ bk. Duman, Beş Surenin Tefsiri, 123-126.

${ }^{80}$ bk. Duman, Beş Surenin Tefsiri, 193-201)

81 bk. Duman, Beş Surenin Tefsiri, 141-143.

82 bk. Duman, Beş Surenin Tefsiri, 202-205.

83 bk. Duman, Beş Surenin Tefsiri, 253-257.

${ }^{84}$ Duman, Kur'an-ı Kerim'de Örtünmenin Sınırları (İstanbul: İpek Yayınları, 2008), 7-11.

85 Duman, Kur'an-ı Kerim'de Örtünmenin Sinırları, 12-13.

${ }^{86}$ Duman, Kur'an-ı Kerim'de Örtünmenin Sinırlarl, 13-14.

87 Duman, Kur'an-ı Kerim'de Örtünmenin Sinırları, 13-17.

88 bk. Duman, "Kuran'da Örtünmenin Temel Sinırları", İslamiyat 4/2 (2001), 35-52.

${ }^{89}$ Duman, Kur'an-ı Kerim'de Örtünmenin Sinırları, 17.
} 
tip ve biçimin belirlenmediğini, her toplumda örtünmenin örfe göre şekillendiğini belirtir. Günümüzde tesettür ile ilgili âyetler hakkındaki tartışmaların Kur'an'ın uygulanıp uygulanamayacağı sorunsalından kaynaklandığını belirten Duman, bu bilgilerin ardından tefsirinin girişinde de yer verdiği tefsir metodolojisine ilişkin bilgilere yer vermektedir. ${ }^{90}$

"Örtünmede Asıl Olan Âyetler" başlıklı birinci bölümde Nur sûresi 30. ve 31. âyeti bağlamında erkek ve kadınların örtünmesiyle ilgili genel düzenlemeler açısından ele alan Duman, âyetleri tarihi bilgi, anahtar kelimeler ve analitik yorum, nakli ve akli deliller çerçevesinde inceler. ${ }^{91}$

"Cilbab Âyeti ve Hükmü" başlıklı ikinci bölümde

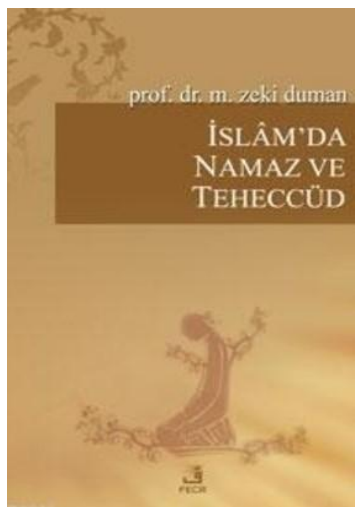
Ahzâb sûresi 59. âyeti aynı yöntemle ele alan Duman, âyetteki cilbab hükmünün ihtiyaç anında kullanılması gereken bir sembol olduğunu, cilbabın toplum ve zamana göre değişiklik gösterebileceğini ve toplumdaki tüm kadınların iffetli olmaları durumunda cilbaba gerek kalmayacağını belirtir. ${ }^{92}$

“Köle ve Cariyelerde Örtünme” başlıklı üçüncü bölümde köle ve cariyelerin örtünmeleri konusuna değinen Duman, İslam'da hür köle ayırımının olmadığını, Müminlerin eşit olduklarını ve örtünme ile ilgili âyetlerin tüm inananları kapsadığını; ayrıca günümüzde kölenin olmadığı ülkemizde bu konunun tartışılmasının gereksiz olduğunu belirtir. İslam'da hür-köle ayırımının sadece had cezalarında olduğunu belirten Duman, cariyelerin örtünmesiyle ilgili görüşlerin Kur'an ve sünnete dayanmadığını, âyetlerdeki hükmün genel olması itibariyle köle ile hürün kulluk sorumluluğu açısından eşit olduğunu ve İslami örfün böyle bir ayırıma müsaade edemeyeceği kanaatindedir. ${ }^{93}$

Duman sonuç olarak örtünmenin kadın ve erkek için bireysel ve sosyal bir gereklilik olduğunu, örtünün biçiminin şeri ve mahalli örfe göre olduğunu, insanın kimliğini tamamlayıcı bir unsur olduğunu, erkeğin ve kadının birbirleri açısından avret-i ğaliza tabir edilen bölgelerine bakmanın haram olduğunu, erkeklerin ise kadınların el ve yüzleri hariç başka ziynetlerine bakmalarının haram olduğunu, bu hükümlerin köle hür herkes için geçerli olduğunu ve sosyal yaşamda vakarlı bir tavır takınılması gerektiğini belirtmiştir. ${ }^{94}$

\subsection{9. İslâm'da Namaz ve Teheccüd}

Birinci ve ikinci olmak üzere iki farklı kitap olarak yayımlanan eser Fecr Yayınevi tarafından 2013 yılında yayımlanmıștır. Birinci kitabın önsözünde namazın bir zikir mecmuası olduğu, bu sebeple namazda zikir ifade eden Fatiha sûresine

\footnotetext{
${ }^{90}$ Duman, Kur'an-ı Kerim'de Örtünmenin Sinırları, 21-31.

91 Duman, Kur'an-ı Kerim'de Örtünmenin Sinırları, 33-79.

92 Duman, Kur'an-ı Kerim'de Örtünmenin Sinırları, 81-85.

93 Duman, Kur'an-ı Kerim'de Örtünmenin Sinırları, 87-98.

${ }^{94}$ Duman, Kur'an-ı Kerim'de Örtünmenin Sinırları, 99-101.
} 
uygun olarak bu anlamı ihtiva eden sûre veya âyetlerin seçilmesi gerektiği, namazda zammı sûre olarak namaz sûreleri olarak bilinen Kur'an'ın son on sûresi ile yetinilmemesi, lafızla mananın, bedenle zikrin birbirine uygunluğuna dikkat edilmesi gerektiği ve kulun dili, zihni ve kalbi ile birlikte uyanık olması gerektiği ifade edilmiştir. Bu eserin, başlangıçta kendisi için seçip namazda okuduğu ve sohbetleri esnasında istek üzere yazılı olarak takdim ettiği dostlarının teşvikiyle yazıldığını belirten Duman, bu eserle namaz bilincini artırmayı hedeflediğini belirtir. ${ }^{95}$

Namazın mahiyetine ilişkin bilgilerin verildiği birinci bölümde İslam'da namaz başlığında iman ve İslam terimleri hakkında bilgi verildikten sonra namazın tarihi süreci ve İslam literatüründeki namazlar hakkında bilgi verilmiş, sonrasında ise çocukların küçük yașta namaza alıştırılmaları gerektiğine değinilmiştir. ${ }^{96}$ Muhtevası itibariyle namaz adlı başlıkta ise namazın zikir, ahde vefa, kulluk bilincinin Allah'a arzı, sıla, bedenen ve ruhen arınarak yücelmek, Allah'a icabet, dinin direği ve iman ile küfür arasındaki perde olduğuna değinilmiştir. ${ }^{97}$ Namazın ikamesi ve ikame şartları başlığında ise "ikame" kelimesi hakkında bilgi verildikten sonra dini literatürde "Namazın dışındaki ve içindeki şartlar" olarak bilinen şartların "Namazın Farzları" olarak verildiği görülmektedir. Bununla birlikte Duman'ın bu şartları namazın içinden ve dışından şeklinde ikili bir taksime tutmadığı ve onlara "vakte riâyet, ihlas, ta'dil-i erkân, huşu ve hudu şartlarını da eklediği görülmektedir. Duman, namazın her durum ve ortamda kılınması gerektiğini, namazın kazası için bir ruhsat olmadığı, bayılma ve koma hali gibi zorunlu durumlar haricinde vakti geçirilmiş ya da kaçırılmış namazın kazasının olmadığını belirtmiştir. Duman, namazın kazasına delil olarak gösterilen hadislerin namaz konusunda ihmalkâr davranmak için delil olmadığını belirtmiştir. ${ }^{98}$

İkinci bölümde ise vitir namazıyla birlikte altı vakit namazın her rekâtı için seçilen âyetlere yer verilmiş, gece namazından sonra kılınan en son namaz olduğu ve imsak vaktine en yakın vakitte kılınması gerektiği için vitir namazının en sonraya bırakıldığı belirtilmiştir. Kitabın sonuç kısmında ise önceki bilgiler özetlenmiştir. ${ }^{99}$

Üç bölümden oluşan ikinci kitabın "Teheccüd (Gece İbadet İçin Kalkmak)” başlığı önsöz ve girișten oluşmaktadır. Önsözde müellif tarafından "Kur'an ile ülfet, Allah ile halvet" olarak tanımlanan teheccüd namazının delili ve teşri süreci ile inananların dünya ve ahiret için faydalarına değinilmiştir. Teheccüdün asıl amacının düşünüp özümseyerek Kur'an okumak olduğunu, zamanla bu ibadetin zikir ve tespihe dönüştürüldügünü belirten Duman, bu eserle teheccüdün asıl amacı ve mahiyetini anlatarak Kur'an okumanın önemine dikkat çekmeyi, Kur'an okumayı ve namazı esas alan yeni bir teheccüd programı sunmayı hedeflediğini ifade etmiş-

\footnotetext{
95 Duman, İslâm'da Namaz ve Teheccüd (Ankara: Fecr Yayınları, 2013), 11-18.

${ }^{96}$ Duman, İslâm'da Namaz ve Teheccüd, 31-48.

97 Duman, İslâm'da Namaz ve Teheccüd, 49-62.

98 Duman, İslâm'da Namaz ve Teheccüd, 80-86.

${ }^{99}$ Duman, Íslâm'da Namaz ve Teheccüd, 87-120.
} 
tir. Ardından da ideal bir gece namazı için tavsiyelerde bulunmaktadır. ${ }^{100}$

Eserin girișinde teheccüd, Hz. Peygamberin gece namazı ve teheccüdün fıkhi hükmü hakkında bilgi verildikten sonra teheccüdle ilgili âyetler ve bu âyetlerin anlam dokusuna değinilmiştir. ${ }^{101}$

“Rasulullah'ın (s.a.v.)'ın Gece Namazları” başlıklı birinci bölümünde Hz. Peygamberin gece namazları hakkındaki rivayetlere değinildikten sonra teheccüde kalkıldığında yapılması tavsiye edilen tertil ile Kur'an okuma, zikir, tespih, dua ve namazdan oluşan ibadetler hakkında âyet ve hadisler ışığında açıklama yapılmıştir. ${ }^{102}$

Kitabın ikinci bölümünde ise her rekatında okunacak âyetler ve mealleri verilerek dokuz rekâtlı gece namazı önerisinde bulunulmuştur. ${ }^{103}$

"Vitir Namazı" başlıklı üçüncü bölümde ise vitir namazının mahiyeti ve kılınışı hakkında bilgi verilmiş, bu namazda okunacak âyet ve dualar mealleriyle birlikte verilmiştir. Ardından gece namazının sonunda yapılması tavsiye edilen tesbihat ve dualara Arapça metinleri ve mealleriyle birlikte yer verilmiştir. ${ }^{104}$

$\mathrm{Bu}$ kitabın sonuç bölümünde ise teheccüdün önemine değinilmiş ve kitabın içeriği özetlenmiştir. ${ }^{105}$

\subsubsection{Hakk'tan Halka Kelâmullah (Levh-i Mahfûz'dan Mushaf-ı Şerife)}

Bu eser Duman'ın vefatının ardından çocuklarının girişimiyle 2016 yılında Fecr Yayınevi tarafından yayımlanmıștır. Levh-i mahfuzun mahiyetine ilişkin soruları cevaplamak için kaleme alındığı belirtilen eser ${ }^{106}$ bir giriș ve üç bölümden olușmaktadır. Eserin girișinde Kur'an'ın Allah tarafından, onun katında bulunan levh-i mahfuzdan indirildiği belirtilmiş; levh-i mahfuzun gerçek mahiyetinin tam olarak bilinemeyeceği, bununla birlikte Kur'an'daki bilgiler sayesinde onun mahiyet ve içeriği hakkında bilgi sahibi olunmasının mümkün olduğu ifade edilmiş, ardından Kur'an'ın üç aşamalı indirilişi hakkında bilgi verilmiştir. ${ }^{107}$

"Levh-i Mahfuz ve Kur'an-ı Kerim" adlı birinci bölümde İslami kaynaklarda Levh-i mahfuza, Kur'an-ı Kerim açısından Levh-i mahfûzun muhtevasına, her şeyin Levh-i mahfûz'da yazılı olmasına, levh-i mahfûz'un kaderle ilişkisine, Levh-i mahfûz'un gerekçesine değinilmiş ve levh-i mahfûz'un gerçekliğine yapılan itirazlara cevap verilmiştir. ${ }^{108}$

\footnotetext{
100 Duman, Íslâm'da Namaz ve Teheccüd, 123-128.

101 Duman, Íslâm'da Namaz ve Teheccüd, 129-147.

102 Duman, İslâm'da Namaz ve Teheccüd, 153-189.

103 Duman, İslâm'da Namaz ve Teheccüd, 191-220.

104 Duman, İslâm'da Namaz ve Teheccüd, 221-249.

105 Duman, İslâm'da Namaz ve Teheccüd, 251-254.

106 Duman, Hakk'tan Halka Kelâmullah (Levh-i Mahfûz'dan Mushaf-ı Şerife) (Ankara: Fecr Yayınları, 2016), 9-10.

107 Duman, Hakk'tan Halka Kelâmullah, 13-20.

${ }^{108}$ Duman, Hakk'tan Halka Kelâmullah, 21-66.
} 
“Kelâmullah'ın Cibril'e İntikali ve Hz. Peygamber'e İnzali” başlıklı ikinci bölümde ise Allah'ın beșer ile konuşması ve yolları, Kelâmullah ile Cibril arasındaki vasıta, Kelâmulah'ın Allah'ın elçisine inzali ve keyfiyeti, inzal edilen âyetlerin mahiyeti konularına değinilmiş, bu bölümde Kur'an'ın Allah kelamı olduğuna ve ona beșer sözü karışmadığına temas edilmiștir. ${ }^{109}$

Üçüncü ve son bölümde ise Kelâmullah'ın yazı ile tespiti, cem'i ve teksiri konularına değinilirken sonuç bölümünde ise Levh-i mahfûzun tüm ilahi kitapların kaynağı olduğu, varlıklara ilişkin tüm bilgilerin kayıtlı olduğu ve Kur'an'ın indiği haliyle muhafaza edildiği vurgulanmıştir. ${ }^{110}$

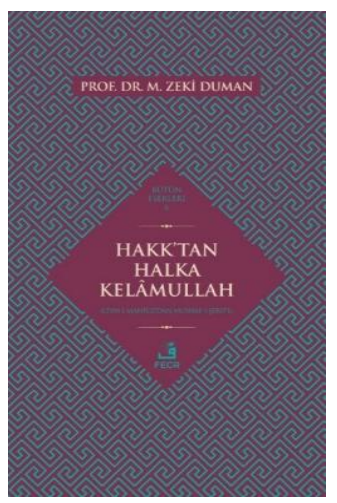

\subsubsection{1. İslam'ın Üzerindeki Beş Gölge-Nesh, Recm, Köle ve Cariye, Ehl-i Beyt ve Hz. İsa'nın Dönüşü-}

$\mathrm{Bu}$ eser Duman'ın vefatının ardından çocuklarının girişimiyle 2019 yılında Fecr Yayınevi tarafından yayımlanmıştır. Eserin, müellifin değindiği konulara ilişkin daha önce kaleme aldığı makalelerin bir araya getirmesiyle oluştuğu anlaşılmaktadır. Duman, esere geçmeden önce bu eserin Kur'an üzerinden tartışılmakta olan bu konuların gerçekten Kur'an'da olup olmadığının halkla paylaşılmak amacıyla kaleme alındığına yönelik bir not düşmektedir. ${ }^{111}$

Eser beş bölümden oluşmaktadır. "Nesh (Kur'an'ı Anlama Problemi) başlıklı birinci bölüm "Kur'an-ı Kerim'de Neshe Delil Gösterilen ve Mensuh Addedilen

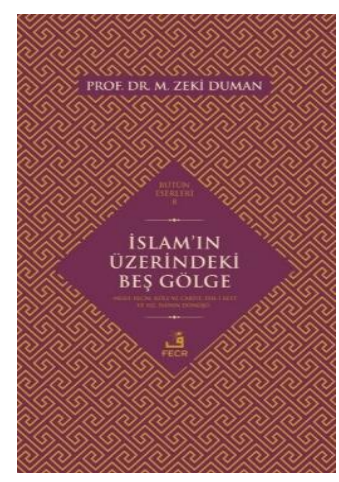
Âyetlerin Mana Yönünden Yeniden Gözden Geçirilip Değerlendirilmeleri”112 adlı makaledeki bilgilerden oluşmaktadır. $\mathrm{Bu}$ bölümde neshe delil gösterilen âyetlerdeki "nesh" ve "âyet" kelimelerinin ilk dönemde sözlük anlamlarıyla yorumlandığı, sonraki dönemde ise bu kelimelere ıstılahi anlam yüklenildiğindiği ve konuya iliş̧in tartışmanın bu dönemde ortaya çıktığı belirtilmiştir. ${ }^{113}$ Ardından Kur'an'ı doğru anlamak için doğru bir tefsir-te'vil anlayışına sahip olmanın önemine değinilmiş ve tefsir ve te'vil kavramları, bu iki kavram arasındaki farklar ve tefsirde temel ilkeler hususlarına temas edilmiştir. Aklen caiz olmakla birlikte Kur'an'ın tevatüren nakledilmesi ve neshe ilişkin rivayetlerin ahad olması sebebiy-

\footnotetext{
109 Duman, Hakk'tan Halka Kelâmullah, 67-153.

110 Duman, Hakk'tan Halka Kelâmullah, 167-170.

111 Duman, İslam’ın Üzerindeki Beş Gölge -Nesh, Recm, Köle ve Cariye, Ehl-i Beyt ve Hz. Ísa'nın Dönüşü(Ankara: Fecr Yayınları, 2019), 9.

112 Krş. Duman, “Kur'an-ı Kerim'de Neshe Delil Gösterilen ve Mensuh Addedilen Âyetlerin Mana Yönünden Yeniden Gözden Geçirilip Değerlendirilmeleri", Bilimname 7/17 (2009), 9-50.

113 Duman, İslam'ın Üzerindeki Beş Gölge, 17-20.
} 
le neshe mesafeli yaklaşılmış, mensuh olduğu ifade edilen âyetlerin uygulama alanının olabileceği sonucuna varılmıştır. ${ }^{114}$

"Recm" başlıklı ikinci bölümde ise müellifin Beş Surenin Tefsiri adlı eserindeki Nûr sûresi ilk beş âyeti hakkındaki yorumları aynen aktardığı görülmektedir. ${ }^{115}$

“Köle ve Cariye (Yanlış Kul ve İnsan Anlayışı)” başlıklı üçüncü bölümde müellifin büyük oranda "İslam'ın Köle ve Cariye Sorununa Yaklaşımı" adlı makalesindeki bilgilerin yer aldığı görülmektedir. Bu bölümde köle ve cariye kavramlarının tanımı, tarihçesi, Kur'an ve sünnetin köle ve cariye sorununa yaklaşımı, köleleştirmeyi yok etmede uygulanan yöntemler, temel hak ve özgürlükler bağlamında köle ve cariyeler, sosyal ilişkiler bağlamında köle ve cariyelere ilişkin getirilen anlayıș, savaş esirlerini köleleştirme geleneğine son verilmesi ve Allah'a kulluk bağlamında mevcut kölelerin tasfiye sürecine değinilmiş, konuya ilişkin sonuç bölümünde de insanın insanlık bilincine ermesi gerektiği ve kendisinin ve başkalarının hukukuna saygılı olması gerektiği vurgulanmıștır. Köleliğin insanlıktan sapma anlamı taşıdığı, İslam'ın gasp edilen bu hakkı sahiplerine geri verdiği; kölelerin inanç ve ibadet hürriyeti, muamelat, ukubat açısından diğer insanlarla eşitlendikten sonra bu kurumun asr-ı saadette kalktığı fakat yeryüzünden tamamen kaldırılamadığına dikkat çekilmiştir. ${ }^{116}$ Ardından cariyelerin örtünme meselesine değinilmiş ve İslam'da inanan cariyelerin Mümin kadınlar gibi tesettüre tam olarak riâyet etmeyecekleri yönündeki anlayışın Kur'an ve sünnete dayanmadığı ifade edilmiştir. ${ }^{117}$

Eserin, "Ehl-i Beyt (Seçilmiş Soy Yaratma Çabası)" başlıklı dördüncü bölümünün müellifin "Kur'ân-ı Kerîm'de "Ehl-i Beyt" adlı makalesinin gözden geçirilmiş hali olduğu görülmektedir. Duman eserin önsözünde Ehl-i Beyt hakkındaki yanlış algıya ve bu algının sonuçlarına değinmiş, 118 girişte ise bu kavramın dini değil siyasi bir anlam taşıdığına dikkat çekmiştir. ${ }^{119}$ Eserde Ehl-i Beyt ile ilgili kelimelerin kavramsal analizi yapıldıktan ${ }^{120}$ sonra bu kavramın tarihi arka planına değinilmiştir. ${ }^{121}$ Ardından bu kavramın geçtiği âyetler incelenmiş, bu kavram ile ilgili tefsirlerdeki farklı görüşler ele alınmıştır. ${ }^{122}$ Sonuç olarak bu kavramın kimleri kapsadığı noktasında dört görüş olduğunu belirten Duman, Kur'an'da bu kavramla müfessirlerin çoğunluğunun belirttiği sadece Hz. Peygamberin hayatta olan eşlerinin kastedildiği yönündeki görüşün doğru olduğunu belirtir. Duman, Kur'an'da Ehl-i Beyt dahil hiç kimsenin günahtan uzak bir fitratta yaratılmadığı yönünde bir ifadenin olmadığına dikkat çeker. ${ }^{123}$

\footnotetext{
114 Duman, İslam'ın Üzerindeki Beş Gölge, 21-80.

115 Duman, Íslam'ın Üzerindeki Beş Gölge, 81-180; krş. Duman, Beş Surenin Tefsiri, 147-207.

116 bk. Duman, İslam'ın Üzerindeki Beș Gölge, 181-257.

117 bk. Duman, İslam'ın Üzerindeki Beș Gölge, 258-262.

118 Duman, İslam'ın Üzerindeki Beş Gölge, 265-269.

119 Duman, İslam'ın Üzerindeki Beş Gölge, 269-270.

120 Duman, İslam'ın Üzerindeki Beș Gölge, 270-274.

121 Duman, İslam'ın Üzerindeki Beș Gölge, 274-280.

122 Duman, İslam'ın Üzerindeki Beş Gölge, 280-313.

123 Duman, İslam'ın Üzerindeki Beș Gölge, 313-319.
} 
“Hz. İsa'nın Dönüşü (Kurtarıcı Beklentisi) başlıklı beșinci bölümün girişinde tüm dinlerin içeriğinin İslam olduğu ve ortak bir hedefinin bulunduğu, Hristiyanlığın muharref bir din olduğu, asli günah inancının Hristiyanlığa sonradan dahil edildiği ve mesih inancının Hz. İsa'nın Hz. Davud'un krallı̆̆ını tekrar yeryüzünde tesis etmesiyle alakalı olduğu; bu görüşün israili rivayetlerle İslam'a geçtiği ve Hz. İsa'nın göğe yükseltildiği, henüz ölmediği ve mehdi kimliği ile yeryüzüne indirileceği yönünde bir inancın oluştuğu ifade edilmiştir. Bu durumun Müslümanların paradoksu olduğunu ifade eden Duman Kur'an'ın Hz. İsa hakkındaki beyanları açık ve net olmasına rağmen bu konudaki tartışmaların devam ettiğini belirtir. Ardından âyetler çerçevesinde Hz. İsa'nın kimliği, ailesi, babasız olarak doğumu ve peygamberliği hakkında bilgi veren Duman, Hz. İsa'yı Yahudilerin öldürmediğini, onun, eceliyle öldükten sonra Rabbinin katına yükseldiğini, bu durumun Hz. İsa'nın mekândan münezzeh olan Allah'ın yanında olması şeklinde değil, şehitlerin Allah katında rızıklandırıldıkları yönündeki âyetlerden hareketle, onların cennette müreffeh bir hayat sürmeleri şeklinde anlaşılması gerektiğini ifade eder. Ardından Hz. İsa'nın nüzûlü tartıșmalarına değinen Duman, hiç kimsenin ölümsüz olamayacağını, Maide sûresi 117. âyetten ${ }^{124} \mathrm{~Hz}$. İsa'nın öldüğünün açıkça anlaşıldığını, ölmüş kimsenin dünyaya tekrar dönmesinin mümkün olamayacağını, Hz. İsa'nın tekrar dünyaya döneceğine delil gösterilen âyetlerin bu anlamı içermediğini, konuya ilişkin yorumların bilimsel bir temele dayanmadığını, Hz. Peygamberin mesajının evrensel olduğunu ve bir mehdiye ihtiyaç olmadığını belirtir. ${ }^{125}$

\subsection{Tamamlanamayan Kitaplarl}

Duman'ın, internet sitesinde verdiği bilgilerden onun, devam eden kitap çalışmalarının bulunduğu, bu eserlerin vefatı sebebiyle tamamlanamadığı anlaşılmaktadır. Bununla birlikte onun, yayımlamayı düşündüğü bazı eserlerdeki birtakım konulara önceki eserlerinde de değindiği görülmektedir. İnternet sitesindeki bilgilerden Duman'ın tamamlanamayan şu çalışmaları olduğu anlaşılmaktadır:

1. Kur'an'ın (İslam'ın) Köle ve Cariye Sorununa Yaklaşımı,

2. Kur'an-ı Kerim'e Göre Hz. Muhammed,

3. Kur'an Açısından Nesh ve Müteşabih Âyetler Meselesi. ${ }^{126}$

\subsection{Makaleleri}

Duman'ın, hakemli ve popüler dergilerde yayımlanan çeşitli konularda makaleleri bulunmaktadır.

124 Âyetin meali şöyldir: "Ben onlara ancak senin bana emrettiklerini söyledim; 'Benim de rabbim sizin de rabbiniz olan Allah'a kulluk edin' dedim. İçlerinde bulunduğum sürece onların yaptıklarına tanık idim. Fakat sen beni vefat ettirdikten sonra onların halini bilip gören sadece sensin. Sen her şeye şahitsin.

125 bk. Duman, İslam'ı Üzerindeki Beş Gölge, 351-354.

${ }^{126}$ Duman, zekiduman.com. 


\subsubsection{Hakemli Dergilerde Yayımlanan Makaleler}

Duman'ın hakemli dergilerde yayımlamış olduğu makaleleri şunlardır:

2.3.1.1. "Kur'an-ı Kerim'de Muharebe ve Zafere Götüren Etkenler", Erciyes Üniversitesi IIlahiyat Fakültesi Dergisi 1 (1983), 179-196.

2.3.1.2. "İnfaka Dair (Zengin Fakir İlişkilerinde Adâb)", Diyanet Dergisi Dini İlmi Edebi 3/21(Temmuz-Ağustos-Eylül 1985), 43-46.

2.3.1.3. "Kur'an'ın Tefsirinde Sahabenin İhtilâfları", Erciyes Üniversitesi İlahiyat Fakültesi Dergisi 2 (1985), 289-310.

2.3.1.4. "Kur'ân'da Naklolunan Yusuf (a.s.) Kıssası Ișığında Görev İsteme Mes'elesi ve Molla Husrev", Diyanet İlmi Dergi [Diyanet Dergisi] 23/3 (1987), 37 46.

2.3.1.5. "Tabiûn Döneminde Tefsir Faaliyeti (Meşhur Müfessirler, Kaynakları ve Bu Tefsirin Değeri)", Erciyes Üniversitesi Ilahiyat Fakültesi Dergisi 4 (1987), 209238.

2.3.1.6. “Imam Gazzalî’nin Tefsir Anlayışı Metodu ve Tefsiri”, Erciyes Üniversitesi Ilahiyat Fakültesi Dergisi 6 (1989), 61-79.127

2.3.1.7. "Ailede Çocuk Eğitimi ve Lokman Hakim'in Oğluna Nasihatlerinin Düşündürdükleri”, Diyanet Dergisi Dini, İlmî Edebi, 27/3 (1991), 103-116.

2.3.1.8. "Oruç Tutmanın Gerekleri", Diyanet İlmi Dergi [Diyanet Dergisi], 28/1 (1992), 99-102.

2.3.1.9. "Şehidlik ve Faziletleri", Erciyes Üniversitesi Sosyal Bilimler Enstitüsü Dergisi 5 (1994), 429-440.

2.3.1.10. "Vahy Olayı ve Vahy-Peygamber İlişkisi", Erciyes Üniversitesi İlahiyat Fakültesi Dergisi 9 (1996), 23-38.128

2.3.1.11. “On Dört Asırlık Tefsir Birikiminin Kur'an'ın Anlaşılmasındaki Olumsuz Etkileri", Erciyes Üniversitesi İlahiyat Fakültesi Dergisi 10 (1998), 27-48.

2.3.1.12. "İman ve İslâm Gerçeği", Kur'an Mesajl: İlmi Araştırmalar Dergisi 2/22-23-24 (1999), 119-154.

2.3.1.13. “Kur'an'da Örtünmenin Temel Sinırları", İslamiyat 4/2 (2001), 3552.

2.3.1.14. "Kur'ân-ı Kerîm'de Ehl-i Beyt", Erciyes Üniversitesi İlahiyat Fakültesi Dergisi, 11 (2001), 37-58.129

2.3.1.15. “Tefsir'in Temel İlkeleri Çerçevesinde Kur'ân-ı Kerîm'de “Ehl-i

127 Bu makale müellifin “Gazâlî’nin Tefsir Metodu”, Ebû Hâmid Muhammed el-Gazâli (1058-1111)”, ed. Ahmet Hulusi Köker (Kayseri: Erciyes Üniversitesi Gevher Nesibe Tıp Tarihi Enstitüsü, 1988), 183200 adlı bildirisinin gözden geçirilmiş halidir.

${ }^{128} \mathrm{Bu}$ makale müellifin "Vahy Olayı ve Peygamber Efendimizin Vahy Karşısındaki Durumu”, İslam'da İnsan Modeli ve Hz. Peygamber Örneği, (Ankara: Türkiye Diyanet Vakfı Yayınları, 1995), 77-90 adlı bildirinin gözden geçirilerek yayımlanmış halidir.

${ }^{129} \mathrm{Bu}$ makalenin konuya ilişkin daha önce yayımlanmış iki makalede görülen eksikliği tamamlamak için kaleme alındığı belirtilmektedir. bk. Kur'ân-ı Kerîm'de “Ehl-i Beyt”, 37. 
Beyt”, Marife: Dini Araştırmalar Dergisi 4/3 (2004), 7-36.130

2.3.1.16. "Kur'an'da Müteşabihât”, Bilimname 3/9 (2005), 13-37.

2.3.1.17. "Müteşâbihâtın Te'vili", Bilimname 3/9 (2005), 39-54.131

2.3.1.18. "Nur Sûresi'nin 35. Âyetinin Tefsir ve Te'vili Bağlamında Allah'ın İnsana Dört Hidâyeti: Fitri Din, Akıl, Peygamber ve Kitap", Usûl: İslâm Araştırmaları 3 (2005), 7-42.

2.3.1.19. “Levh-i Mahfûz ve Kur'an”, Marife: Dini Araştırmalar Dergisi 8/1 2008, 9-44.

2.3.1.20. “İslam'da “İnsan” Erkek veya Kadından Önce Gelir", Eski Yeni: Üç Aylık Düşünce Dergisi 12 (2009), 31-53.

2.3.1.21. “Kur'an-ı Kerim'de Neshe Delil Gösterilen ve Mensuh Addedilen Âyetlerin Mana Yönünden Yeniden Gözden Geçirilip Değerlendirilmeleri”, Bilimname: Düşünce Platformu 7/14 (2009) 9-50.

2.3.1.22. “Neden Yeni Bir Tefsir?: Beyanü'l-Hak Adlı Eserimizin Özellikleri ve Tefsire Getirdiği Yenilik Hakkında Bir Deneme", Türk Bilimsel Derlemeler Dergisi 2/1 (2009), 105-115. ${ }^{132}$

2.3.1.23. “Kelamullah'ın Levh-i Mahfuz'dan Cibril'e İntikali ve Hz. Peygambere İnzali”, İslâmî İlimler Dergisi 5/1 (2010), 41-90.133

2.3.1.24. "İslam'ın Köle ve Cariye Sorununa Yaklaşımı", Erciyes Üniversitesi İlahiyat Fakültesi Dergisi 12 (2011), 1-54.

2.3.1.25. "İslam Medeniyeti ve Çağdaș Dünya", Erciyes Üniversitesi İlahiyat Fakültesi Dergisi 13 (2011), 1-20.134

\subsubsection{Diğer Dergilerde Yayımlanan Kısa Makaleler}

Duman'ın aktüel dergilerde yayımladığı kısa makaleleri şunlardır:

2.3.2.1. "Allah'a Bağlanıș ve Yönelişte Edeb”, Altınoluk 13 (1 Mart 1987), 1618.

2.3.2.2. "Ahlak Davranışlara Yansıdığı Sürece Ahlak Olur”, (Mülakat: Görüşmeci adı belirtilmemiş), Ribat 17/200 (Ağustos, 1999), 33-38.

2.3.2.3. "Kur'an'da Ziynet Kavramı ve Örtünmedeki Yeri”, Fecre Doğru 51

${ }^{130}$ Bu makalenin, "Kur'ân-ı Kerîm'de Ehl-i Beyt" adlı makalenin farklı bir bakış açısıyla yeniden kaleme alınması sonucu üretildiği ifade edilmektedir. bk. "Tefsir'in Temel İlkeleri Çerçevesinde Kur'ân-1 Kerîm'de "Ehl-i Beyt", 7.

$131 \mathrm{Bu}$ makalenin derginin aynı sayısının 13-37 sayfaları arasında yayımlanan "Kur'an'da Müteşabihât" adlı makalenin devamı olduğu anlaşılmaktadır.

$132 \mathrm{Bu}$ makalenin Duman'ın, Beyânu'l-Hak tefsirinin girișinde konuya ilișkin verdiği bilgilerin genişletilmesiyle ve sistematize edilmesiyle oluşturulduğu anlaşılmaktadır.

133 Duman makalenin girişinde bu çalıșmanın "Levh-i Mahfûz ve Kur'an” adlı makalenin devamı niteliğinde olduğunu belirtmektedir. bk. "Kelamullah'ın Levh-i Mahfuz'dan Cibril'e İntikali”, 41.

134 Bu makale 13-14 Ekim 2011 tarihlerinde Dağıstan Devlet Üniversitesi'nin Mohaçkale'de düzenlemiş olduğu "İslam Medeniyeti ve Çağdaş Dünya" konulu sempozyumda "Allah Merkezli İlk ve Tek Evrensel Medeniyet" adıyla sunulan bildiriden oluşturulmuştur. bk. Duman, "İslam Medeniyeti ve Çağdaş Dünya", 1. 
(Ocak 2000), 51, 3-10.

2.3.2.4. "Kur'an'da Ziynet Kavramı ve Örtünmedeki Yeri", Fecre Doğru 52 (Şubat 2000), 47-52.

2.3.2.5. "Kur'an'da Ziynet Kavramı ve Örtünmedeki Yeri” Fecre Doğru 53 (Mart 2000), 28-32.

2.3.2.6. "Ehl-i Beyt Kavramı Üzerine Kur'an Merkezli Bir Değerlendirme", Fecre Doğru 63 (Ocak 2001), 30-41.

2.3.2.7. “Kader İnsana Değil, İnsan Kaderine Hükmetmelidir!..” Fecre Doğru 68 (Haziran 2001), 3-5.

2.3.2.8. "Kur'an-ı Kerim'de Şefaat ya da Tıkandığı Yerde İnsana Destek Olmak," Fecre Doğru 71 (Eylül 2001), 4-8.

2.3.2.9. "Vasat Ümmet, Hayırlı Ümmet Olgusu Bağlamında Kur'an Ahlakının Sahabenin Hayatına Yansıması", Fecre Doğru, 75 (Ocak 2002) 4-9.

2.3.2.10. "İslam, Kur'an ve İnsan Hakkında Bir Deneme", Fecre Doğru 76 (Şubat 2002), 23-26.

2.3.2.11. “Hz. İsa...”, Fecre Doğru 81 (Temmuz 2002), 16-23.

2.3.2.12. "Hz. İsa..." Fecre Doğru 82 (Ağustos 2002), 33-40.

2.3.2.13. "Fatiha Sûresi ve Taşıdı̆̆ı Anlam Üzerine Bir Değerlendirme”, Nida Düşünce, Kültür, Edebiyat 73 (2003), 38-39.

2.3.2.14. "Kadere İnanan Kederden Emîn Olur!..." Somuncubaba 57 (Temmuz 2005), 22-24.

2.3.2.15. "Ahlâkın Davranışlara Yansıması", Somuncubaba 60, (Ekim 2005), 8-12.

2.3.2.16. "Kur'an-ı Anlamak", Diyanet Aylık Dergi 179 (Kasım 2005), 32-36.

2.3.2.17. "İslâm'da Edeb'in Önemi”, Somuncubaba 64 (Şubat 2006), 16-19.

2.3.2.18. "Ümmet İçin Peygamber, Allah'ın Akıldan Sonraki En Büyük Nimetidir", Íktibas 328 (Nisan 2006), 82-86.

2.3.2.19. "İstikamet”, Nida Düşünce, Kültür, Edebiyat 127 (Mayıs 2008), 4146.

2.3.2.20. "Bireysel ve Sosyal Bir Erdem Olarak Adab-ı Muaşeret", Dem Dergi 4 (Eylül-Ekim-Kasım 2008) 12-17.

2.3.2.21. "Kuran'ı Kerim Açısından İnsanın Yaratılışı ve Tüp Bebek Hadisesi”, Vuslat, 10/133, (Temmuz 2012), 11-18.

\subsection{Bildirileri}

Duman'ın çeşitli sempozyumlarda sunduğu bildirileri şunlardır:

2.4.1. "Türk Gençliğinin Eğitim-Öğretim Sorunu ve Anarşiye Sevk Eden Unsurlar", Uluslararası Terörizm ve Gençlik Sempozyumu, (Sivas: Cumhuriyet Üniversitesi Yayınları, 1986), 193-198.

2.4.2. "Gazâlî̀nin Tefsir Metodu”, Ebû Hâmid Muhammed el-Gazâli (10581111), ed. Ahmet Hulusi Köker, (Kayseri: Erciyes Üniversitesi Gevher Nesibe Tıp 
Tarihi Enstitüsü, 1988), 183-200.

2.4.3. “Kur'an'da Naklolunan Yusuf (a.s) Kıssası Işığında Görev İsteme Meselesi ve Molla Hüsrev, Molla Hüsrev Mehmet Efendi (1400-1480), Kayseri: Erciyes Üniversitesi Matbaası, 1992), 85-96.

2.4.4. "Vahy Olayı ve Peygamber Efendimizin Vahy Karşısındaki Durumu", İslam'da Ínsan Modeli ve Hz. Peygamber Örneği, (Ankara: Türkiye Diyanet Vakfı Yayınları, 1995), 77-90.

2.4.5. "Asr-ı Saadette ve Günümüzde Kur'an ve Müslümanlar, III. Kur'an Haftası Kur'an Sempozyumu, (Ankara: Fecr Yayınları, 1998), 267-293.

2.4.6. "Kur'an'ı Anlamada Temel Prensipler", VII. Kur'an Sempozyumu: Kur'an ve Müslümanlar, (Ankara: Fecr Yayınları, 2005), s. 99-132.

2.4.7. "Asr-ı Saadet'te ve Günümüzde Kur'ân'a Bakıș Açısı”, Kur'ân'ı Nasıl Anlamalıyız?, (Bursa: Kurav Yayınları, 2005), 21-32.

2.4.8. “Tefsir Te'vil ve Tefsirde Temel İlkeler Açısından Secavend"lerde Mânaya Tesir Eden Önemli Üç Hata”, Tarihten Günümüze Kur'an'a Yaklașımlar, ed. Bilal Gökkır vd. (İstanbul: İlim Yayma Vakfi Kur'an ve Tefsir Akademisi, 2010), 467-516.

2.4.9. "Tefsir İlim midir?, Tefsir Nasıl Bir İlimdir?", Tartıșmalı İlmi İhtisas Toplantısı, (İstanbul: Ensar Neşriyat, 2011), 48-56.

2.4.10. “Kur'an'ı Anlama Metod ve İlkeleri”, Kur'an'ın Anlaşılmasına Doğru Tefsir ve Toplum, (İstanbul: 2011: Ensar Neşriyat), 379-426.

2.4.11. "Kur'an'ın Penceresinden Mekke ve Vahyin Mekke Dönemi”, Kur'an Nüzulünün Mekke Dönemi Sempozyumu, ed. Mesut Okumuş, (Çorum: Çorum Belediyesi Kültür Yayınları, 2013), 23-55.

\subsection{Ansiklopedi Maddeleri}

Duman'ın kaleme aldığı ansiklopedi maddeleri şunlardır:

2.5.1. "Ebü'l-Feth ed-Deylemî”, Türkiye Diyanet Vakfı İslâm Ansiklopedisi (İstanbul: TDV Yayınları, 1994), 10/ 319.

2.5.2. "Emel”, Türkiye Diyanet Vakfı İslâm Ansiklopedisi (İstanbul: TDV Yayınları, 1995), 11/87.

2.5.3. "Habîs", Türkiye Diyanet Vakfı İslâm Ansiklopedisi (İstanbul: TDV Yayinları, 1996), 14/379.

2.5.4. "Hablullah", Türkiye Diyanet Vakfı Íslâm Ansiklopedisi (İstanbul: TDV Yayınları, 1996), 14/380.

2.5.6. Hurûf-ı Mukattaa, Türkiye Diyanet Vakfı İslâm Ansiklopedisi (İstanbul: TDV Yayınları, 1998), 401-408 (Mustafa Altundağ ile birlikte hazırlamıştır).

2.5.7. “İbnü'l-Vecîh”, Türkiye Diyanet Vakfı İslâm Ansiklopedisi (İstanbul: TDV Yayınları, 2000), 21/236-237.

2.5.8. "İskenderânî, Îsâ b. Abdülazîz", Türkiye Diyanet Vakfi İslâm Ansiklopedisi (İstanbul: TDV Yayınları, 2000), 22/572-573. 


\subsection{Cevirileri}

Duman'ın sadece aile hayatının önemine ilişkin bir eser tercüme ettiği görülmektedir.

\subsubsection{Cennet Evlerimizde}

Mısırlı yazar Amr Halid'in ailenin önemini anlatan el-Cenne fỉ büyûtinâ adlı eserinin Türkçeye çevirisi olan bu eser Duman hayatta iken çevirisi tamamlanmış olmakla birlikte vefatından sonra yakınları tarafından bastırılmıştır. ${ }^{135}$ Kitapta mutlu bir aile hayatı için eşlerin dikkat etmesi gereken hususlara ve görevlerine değinilmiştir.

\subsection{Yönettiği Tezler}

Duman, yüksek lisans ve doktora aşamalarında çok sayıda tezi yönetmiştir.

\subsubsection{Yüksek Lisans Tezleri}

2.7.1.1. Galip Kaçar, Kur'an-ı Kerim'de Hz. Musa ve Firavun (Kayseri: Erciyes Üniversitesi Sosyal Bilimler Enstitüsü, 1992).

2.7.1.2. Mehmet Çetinkaya, Kayseri Raşid Efendi Kütüphanesi'ndeki Tefsir El Yazmalarının Tanıtılması (Kayseri: Erciyes Üniversitesi Sosyal Bilimler Enstitüsü, 1993).

2.7.1.3. Cansever Dokuz, Kur'an-ı Kerim'de Kadın (Hak ve Sorumlulukları) (Kayseri: Erciyes Üniversitesi Sosyal Bilimler Enstitüsü, 1993).

2.7.1.4. Sedat Akyüz, Kur`an`da Tarih Yorumu (Kayseri: Erciyes Üniversitesi Sosyal Bilimler Enstitüsü, 1995).

2.7.1.5. H. Ali Çakıcı, Kur'an-ı Kerim'de Şirk Kavramı ve Günümüz Açısından Değerlendirilmesi (Kayseri: Erciyes Üniversitesi Sosyal Bilimler Enstitüsü, 1995).

2.7.1.6. Recep Çetintaş, Tefsirde Esbab-ı Nüzul Problemi (Kayseri: Erciyes Üniversitesi Sosyal Bilimler Enstitüsü, 1995).

2.7.1.7. Ekrem Bayat, Şihabud'din Es-Sivasi'nin Uyunu't-Tefasir Adlı Eserinin Tahlili ve Tefsirdeki Metodu (Kayseri: Erciyes Üniversitesi Sosyal Bilimler Enstitüsü, 1995).

2.7.1.8. Mikdat Öccü, Beşeri Münasebetler Açısından Veli ve Velâyet Kavramı (Kayseri: Erciyes Üniversitesi Sosyal Bilimler Enstitüsü, 1996).

2.7.1.9. Şahin Güven, Tefsir Çalışmalarında Konulu Tefsir Metodu (Kayseri: Erciyes Üniversitesi Sosyal Bilimler Enstitüsü, 1996).

2.7.1.10. Rüştü Köse, Nur Sûresinin İkinci ve Üçüncü Âyetlerinin ve İlgili Rivayetlerinin Tahlil ve Değerlendirilmesi (Kayseri: Erciyes Üniversitesi Sosyal Bilimler Enstitüsü, 2002).

2.7.1.11. Abdullah Kılıç, Kur'an-ı Kerim'de Ehl-i Beyt (Kayseri: Erciyes Üni-

${ }^{135}$ Amr Halid, Cennet Evimizde, çev. M. Zeki Duman, (Ankara: Cinas Grafik, 2008). 
versitesi Sosyal Bilimler Enstitüsü, 2002).

2.7.1.12. Ömer Özbek, Bursevi'nin Ruhu'l-Beyan Adlı Tefsirinde 'Usul-i Aşere' (Kayseri: Erciyes Üniversitesi Sosyal Bilimler Enstitüsü, 2003).

2.7.1.13. Hüseyin Yıldırım, Necmeddin Tüfî́nin 'el-İksîr Fî İlmi't-Tefsir Adlı Eserinin Kur'an İlimleri Açısından Değerlendirilmesi (Kayseri: Erciyes Üniversitesi Sosyal Bilimler Enstitüsü, 2005).

2.7.1.14. Ali Rıza Yılmaz, Kur'an-ı Kerim'deki Âsi Kavimlerin Helak OluşSebepleri ve Ortak Yönleri (Kayseri: Erciyes Üniversitesi Sosyal Bilimler Enstitüsü, 2006).

2.7.1.15. Abdülbaki Yazıcı, Tevrat ve Íncil'in İtikat Açısından Kur'an'a Arzı (Kayseri: Erciyes Üniversitesi Sosyal Bilimler Enstitüsü, 2007).

2.7.1.16. Atilla Buğdaycı, Kur'an'ı Kerim'e Göre Üç Semavi Din (YahudilikHiristiyanlık-Íslamiyet) (Kayseri: Erciyes Üniversitesi Sosyal Bilimler Enstitüsü, 2007).

2.7.1.17. Vedat Tekin, Zerkeşî'nin el-Burhân Fî Ulûmi'l-Kur'an'ında Anlama ve Yorum (Kayseri: Erciyes Üniversitesi Sosyal Bilimler Enstitüsü, 2007).

2.7.1.18. Mehmet Kaya, Kemâlüddîn Abdürrezzâk Kâşânî ve Tefsiri Te'vîlâtü'lKur'ân'ın Tefsir Metodolojisi Açısından Tahlil ve Tanıtımı (Kayseri: Erciyes Üniversitesi Sosyal Bilimler Enstitüsü, 2009).

2.7.1.19. Akhmed Aldamov, Kur'ân-ı Kerim'de Peygamberlerin Vasıfları ve Örnek Davranışları (Kayseri: Erciyes Üniversitesi Sosyal Bilimler Enstitüsü, 2010).

2.7.1.20. Hamza Sadan, Ra'd Suresi 31. Ayeti Bağlamında ve Kur'an Bütünlüğü İçerisinde Kur'an'ın Söz Bakımından Etki Gücü (Kayseri: Erciyes Üniversitesi Sosyal Bilimler Enstitüsü, 2010).

2.7.1.21. Arslan Karaoğlan, Konyalı Mehmed Vehbi Efendi'nin Ahkâm-ı Kur'âniye ve Muhammed Ali Es-Sâbûnî'nin Revâiu'l-Beyan Adlı Eserinin Mukayesesi (Kayseri: Erciyes Üniversitesi Sosyal Bilimler Enstitüsü, 2011).

\subsubsection{Doktora Tezleri}

2.7.2.1 Yavuz Fırat, Kur'an-ı Kerim'e Vahiy Sürecinde Oluşan İslam Toplumu (Tedriç ve Tebliğ Yöntemleri Açısından) (Kayseri: Erciyes Üniversitesi Sosyal Bilimler Enstitüsü, 1997).

2.7.2.2. Şahin Güven, Kur'an'ın Anlaşılmasında Çokanlamlılık Sorunu (Kayseri: Erciyes Üniversitesi Sosyal Bilimler Enstitüsü, 2004).

2.7.2.3. Mehmet Demirci, Kurtubi'nin "el-Câmi' li Ahkâmi'l-Kur'an" Adlı Eserinin Tefsir Usulü Açısından Değerlendirilmesi (Kayseri: Erciyes Üniversitesi Sosyal Bilimler Enstitüsü, 2009). 


\section{Sonuç}

Prof. Dr. M. Zeki Duman yıllarca Erciyes Üniversitesi İlahiyat Fakültesi'nde görev yapmış, kaleme aldığı çok sayıda ilmi çalışma ve yetiştirdiği öğrenci ile akademik camiaya değerli katkılar sunmuş bir ilim adamıdır. 0 , bir akademisyen olmakla birlikte kendisini fakülte sınırlarına hapsetmemiş; halkla bütünleşmeyi sağlayabilmiş, hayırda öncü olmuş ve spor hayatında faaliyette bulunmuş ender şahsiyetlerdendir. Bir Ramazan gününde oruçlu iken rahmet-i Rahman'a kavuşmuştur. Vefatı sebebiyle ilmi faaliyetleri son bulsa da bizlere bıraktığı ilmi bakiye ve yapmış olduğu hasenat amel defterinin açık kalmasına vesile olmuştur.

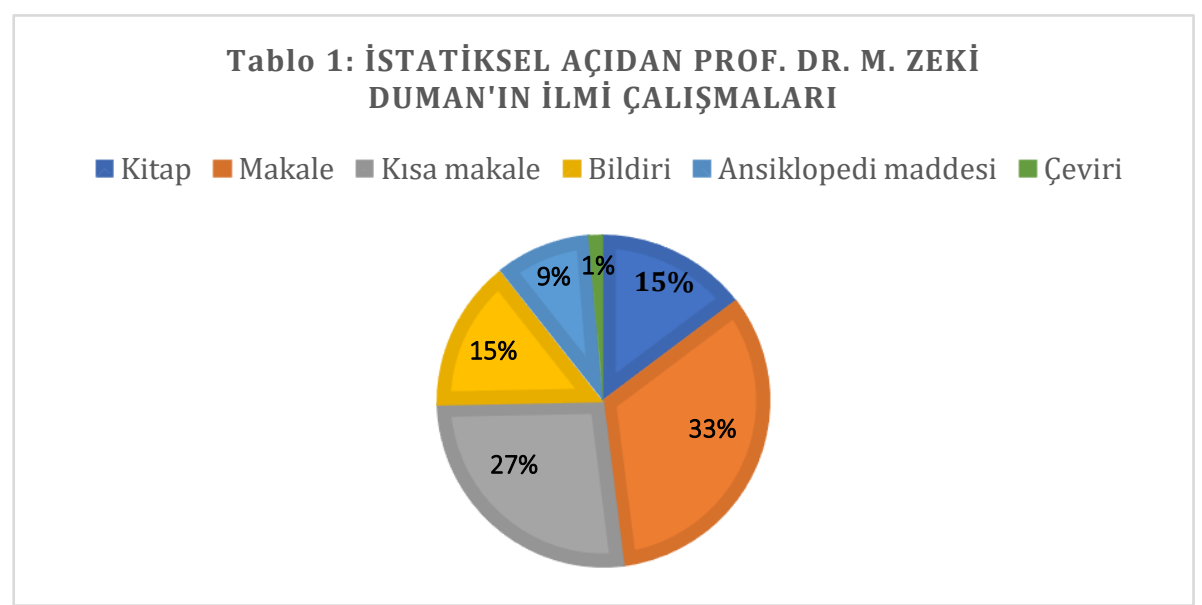

Merhum Duman, çok sayıda kitap, makale, bildiri ansiklopedi maddesi kaleme almış, bununla birlikte sûrelerin nüzûl sıralamasını esas alarak kaleme aldığı Beyânu'l-Hak adlı eseri adeta onun başyapıtı olmuştur. Tespit edebildiğimiz kadarıyla Duman mezkûr tefsiriyle birlikte on bir kitap, hakemli dergilerde yayımlanmış yirmi beş makale, aktüel dergilerde yayımlanmış yirmi bir makale, on bir bildiri, yedi ansiklopedi maddesi ve bir çeviri kitap ile ilim camiasına katkı sağlamış; üzerinde çalıştığı üç kitap çalışmasını ise tamamlamaya muvaffak olamamıştır.

Duman'ın, tefsirini Kur'an bütünlüğü, modern bilimin verileri ve anlaşılır bir dili esas alarak kaleme aldığı, bununla birlikte geleneği de gözettiği görülmektedir. Müellifin, diğer kitaplarında toplumsal konulara ve vahiy olgusuna ağırlık verdiği, bununla birlikte modern bilim, tefsir tarihi ve usulü ile modern dönemde tartışılmaya devam eden konular hakkında da eserler ortaya koyduğu görülmektedir. Duman'ın, kitaplarındaki bazı konulara daha önceki makale ya da bildirilere de değindiği görülmektedir. Duman'ın, makalelerinde nesh ve müteşabihat konularına ağırlık verdiği, bununla birlikte ilk dönem tefsiri, sosyal konular, vahiy olgusu, tefsir ilminin problemleri, çağdaş dünyanın İslam'a yaklaşımı gibi alanlara da eğildiği görülmektedir.

Eser-müfessir incelemesine ilişkin sadece bir çalışması bulunan Duman'ın bazı makalelerinin birbirinin devamı niteliğinde olduğu, bir kısmının ise daha önce yayımlanan bildirilerden oluşturulduğu görülmektedir. Duman'ın, aktüel dergilerde yayımlanan kısa makalelerinde ise toplumun sorunlarına, toplumda tartıșılan 
konulara ve ahlaki meselelere yoğunlaştığı görülmektedir. Bildirilerinde çeşitli konulara temas eden Duman, vahiy olgusu ile tefsirin mahiyeti ve yöntemi konularına eğilmiştir. Duman, şahıs, tefsir usulü ve Kur'an tabirlerine ilişkin çeşitli ansiklopedi maddeleri de kaleme almıştır.

Duman, lisans, yüksek lisans ve doktora dönemlerinde olmak üzere bugün bir kısmı akademisyen olarak çeşitli İlahiyat Fakültelerinde görev yapan çok sayıda öğrenci yetiştirmiştir. Duman, lisans döneminden itibaren çok sayıda teze danışmanlık yapmakla birlikte akademik çalışmaların ilk aşaması kabul edilen yüksek lisans aşamasında yirmi bir, doktora aşamasında ise tamamlanmış üç tezi yönetmiştir. Yönettiği tezler konu itibariyle incelendiğinde Kur'an'ın içeriğine yönelik konuların ağırlık kazandığı; bununla birlikte konu olarak tefsir usulü ve esermüfessir incelemelerinin tercih edildiği görülmektedir.

Duman'ın eserlerinin çeşitli akademik çalışmalara konu olduğu ve bu çalışmaların onun Beyânu'l-Hak tefsiri üzerinde yoğunlaştığı görülmektedir. Bu tefsirin eleştirildiği bir adet de makale kaleme alınmıştır. Duman'ın bilimsel tefsire ilişkin görüşlerinin ele alındığı bir adet çalışma yapılmıştır. Bununla birlikte merhum Duman'ın eserlerinin vahiy olgusu, tefsir tarihi ve usulü, tefsir problemleri ile sosyolojik tefsir açısından akademik çalışmalara konu edinilmesi gerektiği yönündeki kanaatimizi belirtmek yerinde olacaktır.

Funding / Finansman: This research received no external funding. / Bu araştırma herhangi bir dış fon almamıştır.

Acknowledgments / Teşekkür: I would like to thank research assistant Nurullah Haydar Yurduseven, who reviewed the English summary of this research. / Çalışmanın İngilizce özetini gözden geçirme zahmetinde bulunan Ahi Evran Üniversitesi İlahiyat Fakültesi Felsefe ve Din Bilimleri ABD Araştırma Görevlisi Nurullah Haydar YURDUSEVEN'e teşekkürlerimi sunarım.

Conflicts of Interest / Çıkar Çatışması: The author declare no conflict of interest. / Yazar, herhangi bir çıkar çatışması olmadığını beyan eder.

\section{Kaynakça}

Akalp, Melahat. Metodu ve Konuları İtibariyle Beyânu'l-Hak Tefsiri. Konya: Necmeddin Erbakan Üniversitesi, Yüksek Lisans Tezi, 2013.

Duman, M. Zeki. Adab-ı Muaşeret Görgü Kuralları. İstanbul: İpek Yayın Dağıtım, 2003.

Duman, M. Zeki. "Ailede Çocuk Eğitimi ve Lokman Hakim'in Oğluna Nasihatlerinin Düşündürdükleri". Diyanet İlmi Dergi 27/3 (1991). 103-116.

Duman, M. Zeki. Beş Sûrenin Tefsiri (Fatiha, Ahzab, Nûr, Hucurat, Mümtahine). Ankara: Fecr Yayınları, Birinci Basım, 1999.

Duman, M. Zeki. Beyânu'l-Hak (Kur'ân-ı Kerîm'in Nüzul Sırasına Göre Tefsiri). 3 Cilt. Ankara: Fecr Yayınları, İkinci Basım. 2006.

Duman, M. Zeki. İslâm'da Namaz ve Teheccüd. Ankara: Fecr Yayınları, İkinci Basım, 2013.

Duman, M. Zeki. İslam'ın Üzerindeki Beș Gölge -Nesh, Recm, Köle ve Cariye, Ehl-i Beyt ve Hz. İsa'nın Dönüşü-. Ankara: Fecr Yayınları, Birinci Basım, 2019.

Duman, M. Zeki. “Kur'an'da Müteşabihât”. Bilimname 3/9 (2005), 13-37.

Duman, M. Zeki. "Kuran'da Örtünmenin Temel Sınırları". İslamiyat 4/2 (2001), 35-52.

Duman, M. Zeki. “Kur'an-ı Kerim'de Neshe Delil Gösterilen ve Mensuh Addedilen Âyetlerin 
Mana Yönünden Yeniden Gözden Geçirilip Değerlendirilmeleri”. Bilimname 7/17 (2009), 9-50.

Duman, M. Zeki. Kur'an-ı Kerim'de Örtünmenin Sinırları. İstanbul: İpek Yayınları, Birinci Basım, 2008.

Duman, M. Zeki. Kur'an-ı Kerim ve Tıbba Göre İnsanın Yaratılışı ve Tüp Bebek Hadisesi. İzmir: Nil Yayınları, 1991.

Duman, M. Zeki. Nüzulünden Günümüze Kur'an ve Müslümanlar (Nasıl Okudular, Nasıl Okumalıyız?). Ankara: Fecr Yayınları, İkinci Basım, 1997.

Duman, M. Zeki. Uygulamalı Tefsir Usulü ve Tefsir Tarihi (Başlangıcından Tedvin Dönemine Kadar). Kayseri: Erciyes Üniversitesi Yayınları, 1992.

Duman, M. Zeki. Vahiy Gerçeği. Ankara: Fecr Yayınları, Birinci Basım, 1997.

Erünsel, İsmail vd. İlahiyat Fakülteleri Tezler Kataloğu I (1953-2000). İstanbul: İsam Yayınları, 2008.

(IDP) "İslamcl Dergiler Projesi". Erișim 29 Mayıs 2020. https://katalog.idp.org.tr/yazarlar/23230/zeki-duman

(İSAM) "İsam İlahiyat Makaleler Veritabanı". Erişim 28 Mayıs 2020. http://ktp.isam.org.tr/?url=makaleilh/findrecords.php

Somuncubaba İlim, Kültür ve Edebiyat Dergisi. Erişim 02.01.2021. https://www.somuncubaba.net/pdf/eskisayi/

Türkiye Diyanet Vakfı İslam Ansiklopedisi. "Müellif-M. Zeki Duman”. Erişim 27 Mayıs 2020. https://islamansiklopedisi.org.tr/muellif/m-zeki-duman

(YÖK) Yüksek Öğretim Kurulu. "Yüksek Öğretim Kurulu Ulusal Tez Merkezi" Erișim 10 Aralık 2020. https://tez.yok.gov.tr/UlusalTezMerkezi/tezSorguSonucYeni.jsp

Zeki Duman. Erişim 28 Mayıs 2020. http://zekiduman.com/hakk\%C4\%B1nda.html 